\title{
Assessment of greenhouse gases (GHG) emissions from the tallow biodiesel production chain including land use change (LUC)
}

\author{
Victor Paulo Peçanha Esteves ${ }^{\mathrm{a},{ }^{*}}$, Elisa Maria Mano Esteves ${ }^{\mathrm{b}}$, Davi José Bungenstab ${ }^{\mathrm{c}}$, \\ Gelson Luís Dias Feijó ${ }^{c}$, Ofélia de Queiroz Fernandes Araújo a, \\ Cláudia do Rosário Vaz Morgado ${ }^{\mathrm{b}}$
}

a Program in Chemical and Biochemical Process Technology (TPQB), Federal University of Rio de Janeiro, Rio de Janeiro, RJ, Brazil

${ }^{\mathrm{b}}$ Environmental Engineering Program (PEA), Federal University of Rio de Janeiro, Rio de Janeiro, RJ, Brazil

c National Center for Beef Cattle Research (CNPGC), Brazilian Agricultural Research Corporation (Embrapa), Campo Grande, MS, Brazil

\section{A R T I C L E I N F O}

\section{Article history:}

Received 11 November 2016

Received in revised form

8 March 2017

Accepted 9 March 2017

Available online 16 March 2017

\section{Keywords:}

Tallow biodiesel

Life cycle assessment

Inventory allocation

Land use change

Greenhouse gases emissions

Livestock

\begin{abstract}
A B S T R A C T
Economic uncertainties and environmental constraints regarding fossil fuels have encouraged initiatives for renewable energy sources and assessment of their life cycle impacts. Brazil ranks second worldwide in biodiesel production, despite the relatively recent organization of its national chain, marked by the creation of the National Program for Biodiesel Production and Use (PNPB). The Central-West region is responsible for the largest share of biodiesel production (44.4\%) and the largest cattle slaughter (37.5\%). In this scenario, beef tallow has great potential for expansion of biodiesel production, since it is a byproduct of the chain that, when not properly disposed, presents a considerable environmental burden. This work presents a method for assessing environmental performance that integrates life cycle assessment (LCA) with land use change (LUC) for analysis of the tallow biodiesel production chain. The results are given in terms of increment in annual greenhouse gases (GHG) emissions per hectare related to local tallow biodiesel. The system's boundary covers a representative major cattle farming area in Central-West Brazil. For the LCA segment of the method, five inventory allocations were considered: (i) without allocation, (ii) mass, (iii) market value, (iv) energy and (v) an "average allocation", calculated as the mean of mass, market value and energy. The last one is a novel approach proposed in this work, aggregating all the others, which separately result in under or over estimation of impacts. Using the "average allocation", the increment in annual GHG emission per hectare from tallow biodiesel production, is $43.2 \mathrm{~kg} \mathrm{CO}_{2}$ eq ha $\mathrm{ha}^{-1} \mathrm{y}^{-1}$. This value is $17 \%$ less than the emission increment due to soybean biodiesel $\left(50.2 \mathrm{~kg} \mathrm{CO}_{2} \mathrm{eq} \mathrm{ha} \mathrm{h}^{-1} \mathrm{y}^{-1}\right.$ ). LUC is responsible for $96 \%$ of the emission assessed, which demonstrates the importance of including LUC assessment in life cycle assessment of tallow biodiesel. According to the sensitivity analyses performed, changes from crop to pasture have superior environmental performance among the investigated options. Land use management is essential to preserve the remaining natural areas, making tallow biodiesel more sustainable.
\end{abstract}

๑) 2017 Elsevier Ltd. All rights reserved.

\section{Introduction}

Uncertainty about oil availability and its price volatility, aggravated by increasingly stringent environmental regulations regarding climate change caused by anthropogenic greenhouse gases (GHG), have encouraged growth of renewable fuels in the global market (Rico and Sauer, 2015). In Brazil, most of the biofuels

\footnotetext{
* Corresponding author.

E-mail address: victoresteves@poli.ufrj.br (V.P.P. Esteves).
}

come from agriculture, having an important role in domestic agribusiness through new market possibilities for animal and vegetal farm products (Bergmann et al., 2013). The first biofuel commercially produced in Brazil was sugarcane ethanol in the mid1970s, with strong public incentives through the "Pro-Álcool" program. In 2005, encouragement of biodiesel production was renewed through the National Program for Biodiesel Production and Use (PNPB), and in 2015 Brazilian biodiesel production reached 3.94 million $\mathrm{m}^{3}$ (ANP, 2016b), placing the country as the second largest producer worldwide (OECD/FAO, 2015).

Biodiesel is obtained by transesterification of plant oils, tallow 
or fats with short-chain alcohols (e.g., ethanol and methanol). The country has 53 biodiesel plants, with total installed capacity of 7.43 million $\mathrm{m}^{3}$ per year. In 2015 the Central-West was responsible for $44.4 \%$ of Brazilian biodiesel production. Soybean oil and beef tallow are the major raw materials used, corresponding to $85.6 \%$ and $10.3 \%$ for the Central-West, and $75.1 \%$ and $19.2 \%$ for Brazil as a whole (ANP, 2016a) (Fig. 1). Despite their large contribution regarding the biodiesel chain, these feedstocks, especially tallow, are byproducts of Brazilian agribusiness (Rico and Sauer, 2015).

Besides large grain production, representing $42.5 \%$ of the national harvest in 2014-15 (CONAB, 2016), the Brazilian Central-West also has the largest cattle herd in the country (Fig. 2), with 71 million head, which represents $33.5 \%$ of the national total and $37.5 \%$ of slaughter (12.7 million head slaughtered) (IBGE, 2016a). The beef chain has grown strongly in recent decades, currently making Brazil the second largest producer (15.3\%) and the largest beef exporter (19.6\%) in the world (USDA, 2016). In the same period, while Brazilian grazing areas expanded $4 \%$ countrywide, in the Central-West there was 7\% reduction (IBGE, 2016b). This can be explained by crop farming and afforestation expansion on sown pasture areas. Low expansion rates together with herd growth indicate higher stocking rates, showing a tendency to intensification. According to Dick et al. (2015), pasture intensification reduces land use 32 times with GHG emission increase of only $0.5 \%$ from the reference scenario. Nevertheless, the Brazilian beef sector remains under pressure to meet international standards of sustainability and to reduce GHG emissions (Ruviaro et al., 2015).

Moreover, Brazilian cattle systems are based on grazing in sown pastures, with regional average stocking rates around 1.2 head per hectare (Fig. 3) (IBGE, 2016b). Grazing areas are usually located in poor soil zones, more sensitive to losses of fertility, making action necessary to reclaim these areas (Almeida et al., 2013). Integrated crop-livestock systems proposed by local agricultural research institutions have been shown to be a suitable alternative for such cases (Figueiredo et al., 2017).

Tallow is a byproduct of the cattle slaughtering process, together with hides, blood, bones and innards. The use of animal fat can avoid improper disposal, without treatment, in water bodies (Pereira et al., 2012). Beef tallow is a low-value feedstock that, if

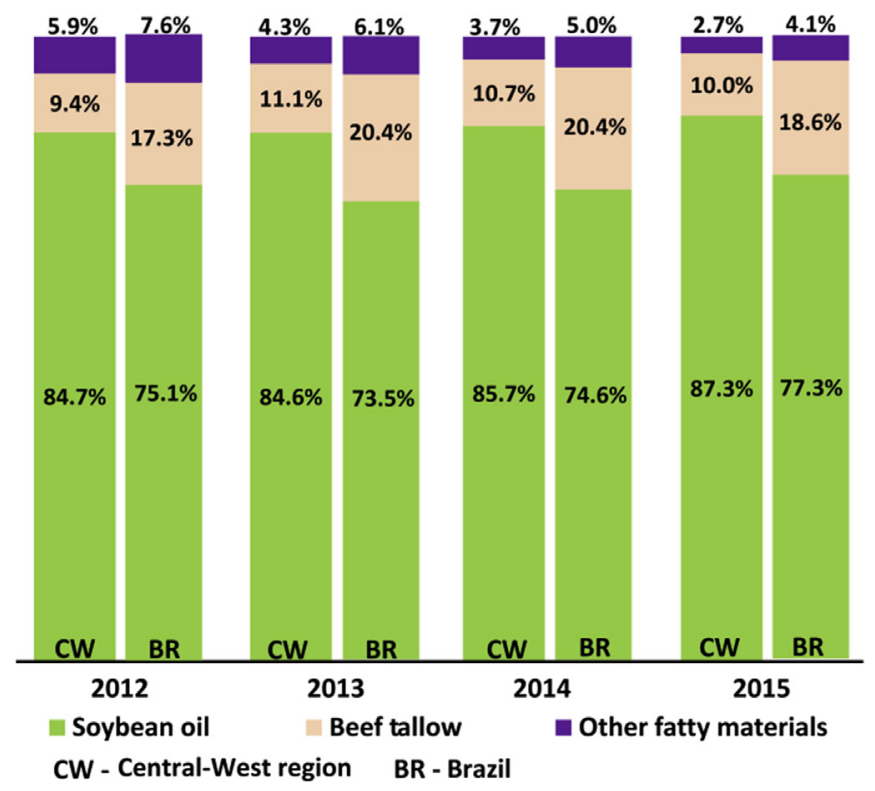

Fig. 1. Feedstock used for biodiesel production in Brazil's Central-West region and Brazil as a whole.

Source: ANP (2016a).

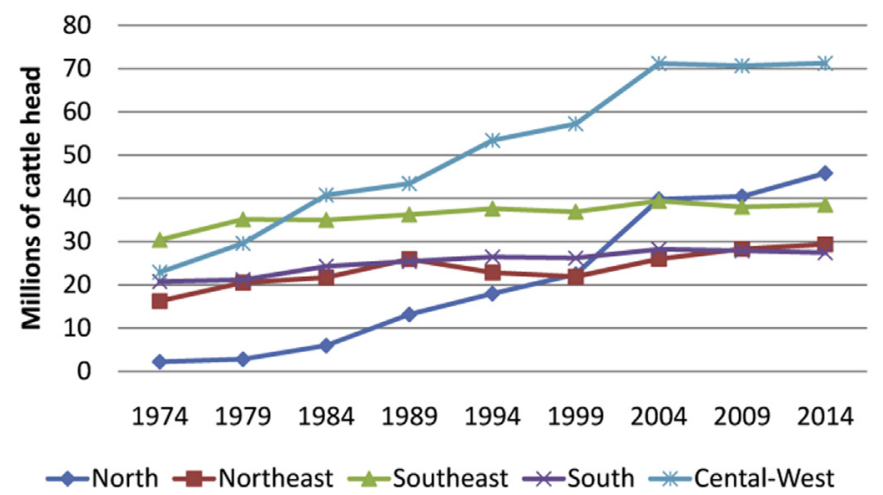

Fig. 2. Cattle herd growth in Brazil, by region. Source: IBGE, 2016a.

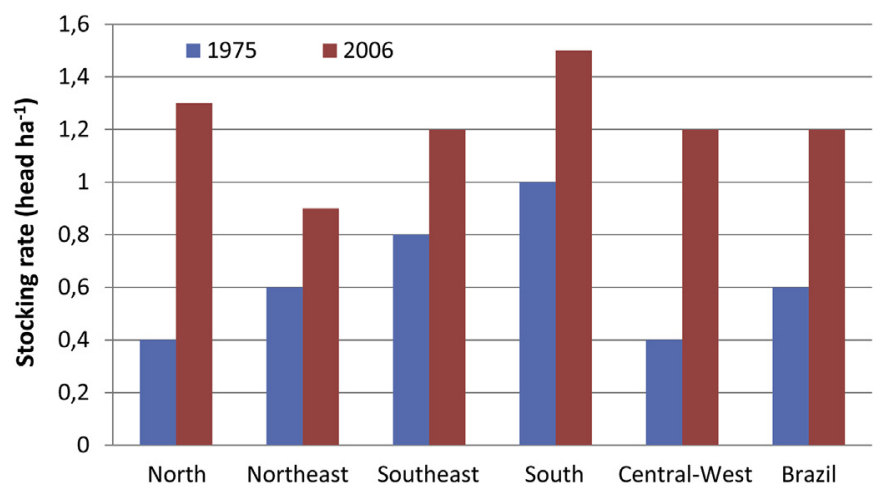

Fig. 3. Stocking rate evolution in Brazil. Source: IBGE, 2016b.

converted to biodiesel, offers a wide range of energy, environmental, and economic advantages (Nelson and Schrock, 2006). From 2005 to 2007 (two years after the beginning of the PNPB), tallow processing into biodiesel increased almost six times. In 2010, biodiesel production was the main destination for tallow, representing about $72 \%$ of the total tallow consumed in the country. Besides being used for biofuel production, it is also employed by the cosmetic, pharmaceutical, pet food and chemical industries (Castanheira et al., 2014).

Before the emergence of tallow demand for biodiesel, it was frequently incinerated or disposed in landfills. Integrated use of industrial residues is now encouraged, to reduce environmental impacts of slaughterhouses (Cunha et al., 2009). Since tallow is a byproduct of the food industry, fuels from this feedstock have lower production costs when compared to other biofuels (Pereira et al., 2012). Additionally, biodiesel from animal fats has high quality and good conversion rates (Cunha et al., 2009), satisfying most requirements of the EM 14214 standard of the European Committee for Standardization (Encinar et al., 2011).

However, the increased use of beef tallow faces some challenges that have to be solved: a) the cattle industry has inelastic supply (Brander et al., 2009); b) the logistics and distribution networks are poor (Castanheira et al., 2014); and c) competition exists with other tallow markets such as cosmetic and soap production, among other uses (Rincón et al., 2014). In this respect, the present article presents a procedure to support policymakers and stakeholders to overcome the barriers to effective utilization of tallow.

Considering the large share of the Central-West region in Brazilian soybean and cattle production, the region is a global player in these commodities, which represent great potential for biodiesel production. In recent decades, there has been relatively little deforestation in the area, but it has gone through important land 


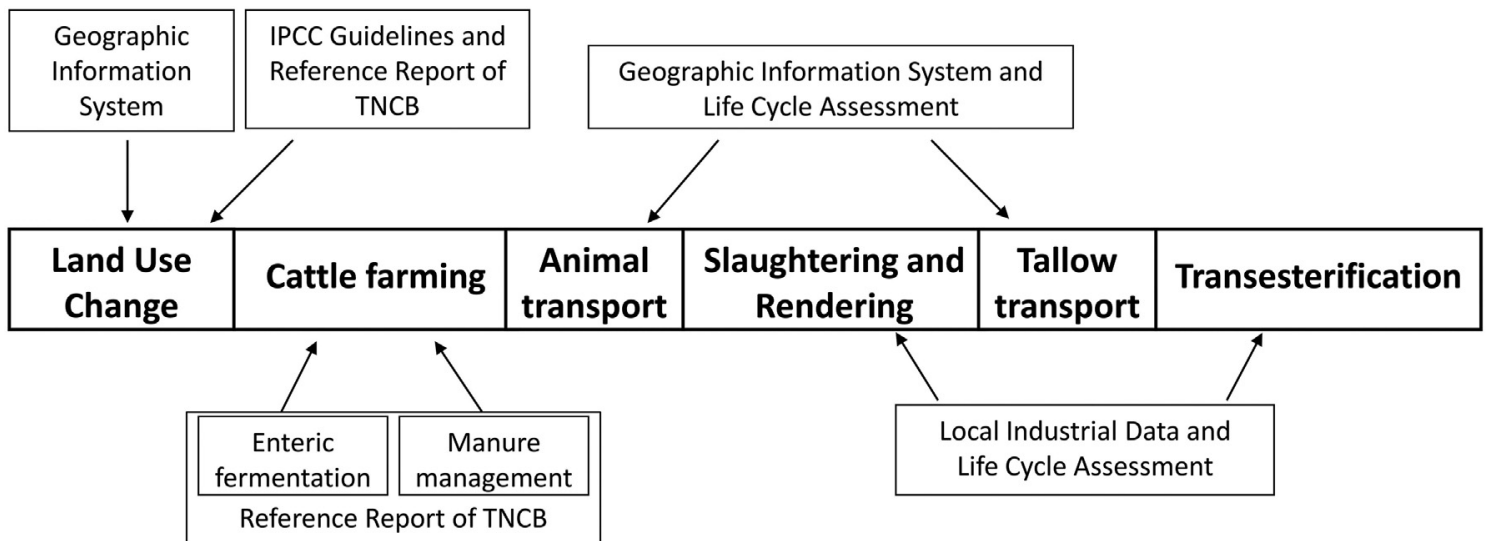

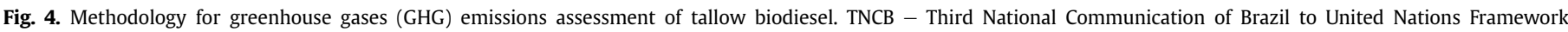
Convention on Climate Change.

use changes (LUC) related to cattle and soybean farming (Siqueira and Duru, 2016).

The topic of GHG emissions from tallow biodiesel production is not new in the literature. Rincón et al. (2014) compared environmental impacts of five biodiesel feedstocks in chemical process simulation. Dufour and Iribarren (2012) assessed the life cycle of esterification-transesterification of waste vegetable oils and animal fats. Nogueira (2011) presented a benchmarking of different productive systems for four biodiesel raw materials. Thamsiriroj and Murphy (2011a) employed three methods to examine tallow and used cooking oil for biodiesel sustainability. Thamsiriroj and Murphy (2011b) assessed GHG emissions for sustainable supply of biofuel, highlighting the effect of the allocation methodology. Niederl-Schmidinger and Narodoslawsky (2008) evaluated two different system boundaries of the tallow biodiesel process, including or excluding beef production and slaughtering phases.

However, only Niederl-Schmidinger and Narodoslawsky (2008) included cattle farming in their analysis and none of them included LUC. To the best of our knowledge, there is a literature gap in assessing the influence of LUC on emissions from tallow biodiesel production.

Considering the potential benefits and challenges of tallow biodiesel production in Brazil, along with different patterns of LUC registered in the country, this work addresses an important research gap on the subject, developing a dedicated approach for regional life cycle assessment (LCA) of biodiesel, focusing in GHG and LUC. The results are relevant for policymakers regarding agriculture and renewable energy production in the area. Due to the

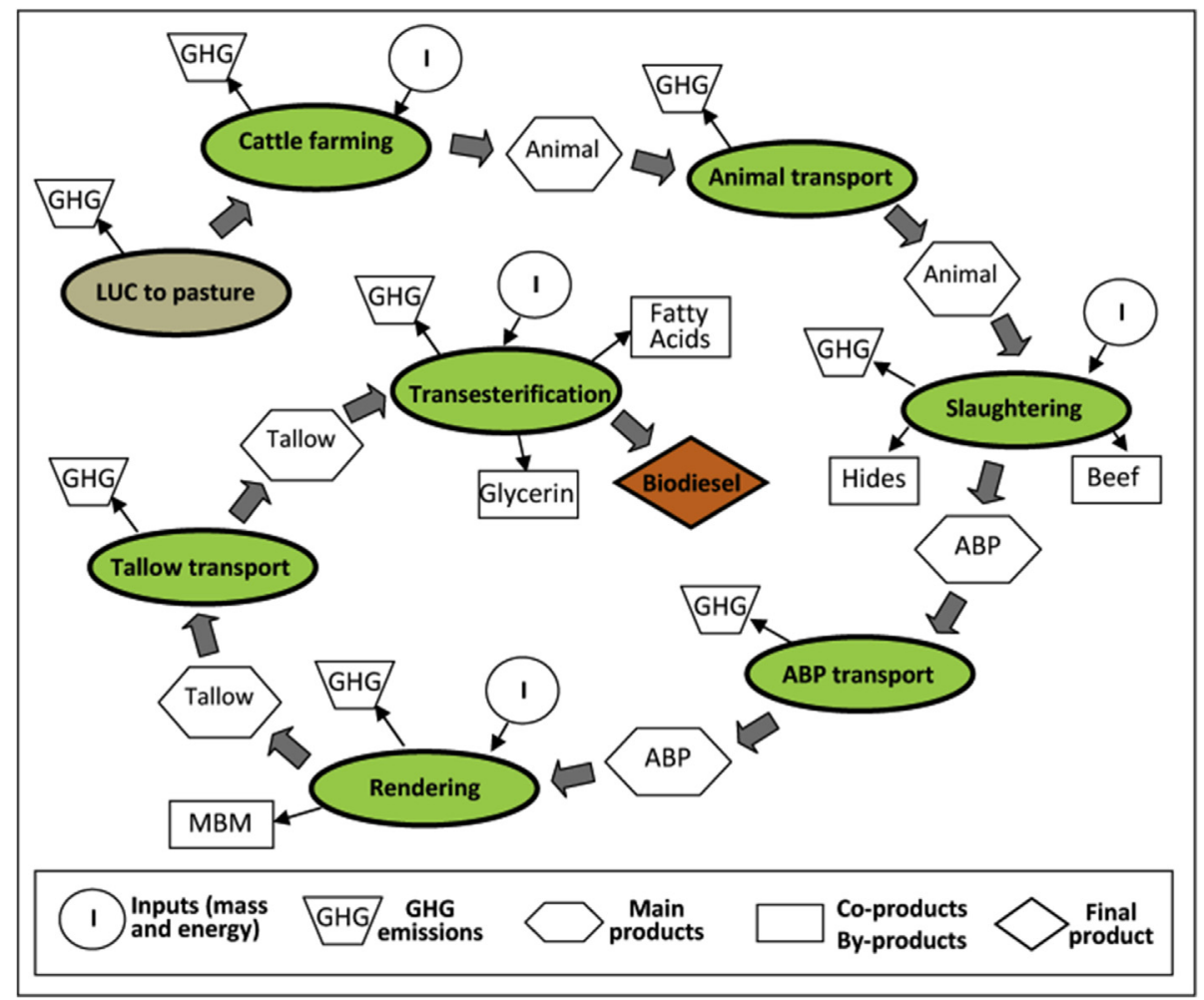

Fig. 5. Tallow biodiesel production flow. MBM - Meat and bone meal; ABP - Animal byproduct; GHG - Greenhouse gases. 
importance of the Brazilian Central-West's agriculture, even on a global scale, the results of this work stand as a reference in comparing the environmental efficiency of different biofuel sources around the world.

This paper is divided into four sections. Following this introduction, Section 2 introduces a new method used to calculate the increment in annual GHG emissions per area, using a geographic information system (GIS) tool and data from the Brazilian GHG inventory to assess emissions due to LUC and cattle farming phases. Data from local farms and industries are entered in the LCA software SIMAPRO $^{\circledR}$ (Pre-sustainability, 2016) to calculate industrial and transport emissions. Still in Section 2, allocation approaches are presented, to allow distributing impacts among products, done in Section 3. Beside this, Section 3 includes the premises, input data and calculations, and discusses the results. The conclusions of the study are presented in Section 4.

\section{Methodology}

The analysis considers LUC to pasture in the past 20 years, together with LCA of beef tallow biodiesel, with the production chain extending from cattle farming to the transesterification unit, with a case study of the Brazilian Central-West region. Fig. 4 summarizes the methodology used in this work.

The steps of the tallow biodiesel production counted in this work are presented in Fig. 5. Each step shows its mass and energy inputs and their main outputs, besides GHG emissions. Some steps have by- or co-product outputs. It is important to mention that "main product" does not mean the product with the highest commercial value, but rather the product used in the next phase of the production chain.

LUC assessment is based on satellite images, following the procedures adopted in Esteves et al. (2016) and detailed in item 2.1. Sown pasture areas are mapped for the final year of the study. For these areas, land uses are identified for the initial year, producing LUC results. The calculation of emissions due to LUC relies on IPCC (Intergovernmental Panel on Climate Change) standards, applying regional data from the Third National Communication of Brazil to the UNFCCC (United Nations Framework Convention on Climate Change), detailed at item 2.2. For the cattle farming phase, this work considers only enteric emissions from cattle and manure management (detailed in item 2.3.1). Animal transport is calculated using the distance between a central point of each municipality's grazing area to each slaughterhouse, considering the shortest paths over local roads.

At slaughter, besides co-products beef and hides, animal byproducts (ABP) are produced, which compose the main resource for the next phase of the chain. In most of the packing plants, rendering is integrated with slaughtering, here referred to as slaughtering \& rendering ( $\mathrm{S} \& \mathrm{R})$, and $\mathrm{ABP}$ transport is not considered. At rendering, besides tallow, meat and bone meal (MBM) are generated, which can be used for non-ruminant feed production or burned. Tallow transport from S\&R to transesterification facilities considers the shortest road distances. In the transesterification phase, besides biodiesel, the byproducts crude glycerin and fatty acids are obtained. This work focuses on local systems to support future comparisons with other regions of the globe, using data from local industries ( $\& \& R$ and transesterification steps).

Data on industrial processes and transportations are inputs to the LCA software SIMAPRO ${ }^{\circledR}$ (Pre-sustainability, 2016), used to quantify emissions.

The increment in annual GHG emissions of tallow biodiesel production per area is calculated using equation (1).
$\Delta E=\frac{\sum_{i}\left[L U C_{e(i-P t)}+B D_{e}\right] \times A_{i-P t}}{A_{T}}$

where $\Delta \mathrm{E}\left(\mathrm{kg} \mathrm{CO}_{2} \mathrm{eq} \mathrm{ha} \mathrm{h}^{-1} \mathrm{y}^{-1}\right)$ is the increment in annual GHG emissions of tallow biodiesel per area; " $i$ " is previous land use, which can be crop (Cp), forest (F) or savannah (Sv); $L U C_{e(i-P t)}(\mathrm{kg}$ $\mathrm{CO}_{2}$ eq ha $\left.{ }^{-1} \mathrm{y}^{-1}\right)$ is the annual emission due to change from previous land use " $i$ " to pasture $(\mathrm{Pt}) ; B D_{e}\left(\mathrm{~kg} \mathrm{CO}_{2}\right.$ eq ha $\left.{ }^{-1} \mathrm{y}^{-1}\right)$ is annual GHG emission from biodiesel production; $A_{i-P t}(\mathrm{ha})$ is the area that changes from land use " $i$ " to pasture (Pt); and $A_{T}$ (ha) is total area under analysis.

\subsection{Method to identify land use by visual interpretation of satellite images}

As in Esteves et al. (2016), sown pasture areas are identified through Landsat satellite images for the final year and then compared to the images from the initial year. The images used are a combination of three bands available from Landsat, yielding images in false-color composition, with spectral information outside the sensitive range of the human eye (USGS, 2016), supporting identification and differentiation of land use classes under study. Areas are broadly classified as "natural areas" (forest and savannah) and "agricultural areas" (pasture and crop farming, mostly soybeans), following the color and texture patterns characteristic of each of these classes. Fig. 6 illustrates the image processing method, showing the main characteristics of each class analyzed: i.e., sown pasture with non-uniform color and smooth texture in each batch; crop farming with uniform color and smooth texture in each batch; rainforest with red color due to intense photosynthetic activity and wrinkled texture caused by tree shading; savannah with red and green color and slightly wrinkled texture.

\subsection{Method to estimate emissions from LUC}

To estimate emissions from LUC, this work follows:

- IPCC Guidelines for National Greenhouse Gas Inventories Volume 4: Agriculture, Forestry and other Land Use (IPCC, 2006);

- IPCC Good Practice Guidance for Land Use, Land-Use Change and Forestry (IPCC, 2003);

- Reference Report of Land Use and Land Use Change and Forestry (LULUCF), a section of the Third National Communication of Brazil to the United Nations Framework Convention on Climate Change (MSTI, 2015b).

Since the aim of this work is to evaluate emissions due to tallow biodiesel, only emissions caused by changes from other land uses to grazing are considered. Total emissions from $L U C\left(L U C_{e}\right)$ include carbon dioxide $\left(\mathrm{LUCe}_{\mathrm{CO}_{2}}\right)$ and nitrous oxide emissions $\left(\mathrm{LUCe}_{\mathrm{N}_{2} \mathrm{O}}\right)$, and are calculated using equations (2)-(12).

$$
\begin{aligned}
& L U C_{e}=L U C_{e O_{2}}+L U C_{e N_{2} \mathrm{O}} \\
& L U C_{e \mathrm{CO}_{2}}=\sum_{i}\left[\left(C S_{i}-C S_{P t}\right) \times(44 / 12)\right] / N_{y}
\end{aligned}
$$

where $C S_{i}\left(\mathrm{~kg} \mathrm{C} \mathrm{ha}^{-1}\right)$ is carbon stock of previous land use " $i$ ", where " $i$ " can be crop (Cp), forest (F) or savannah (Sv); $C S_{P t}\left(\mathrm{~kg} \mathrm{C} \mathrm{ha}^{-1}\right)$ is the carbon stock of pasture (Pt); fraction $44 / 12$ is the rate of carbon 
dioxide molecular mass (emitted) and carbon molecular mass (stock), used for conversion of $\mathrm{C}$ to $\mathrm{CO}_{2}$; and $\mathrm{N}_{y}(\mathrm{y})$ is the number of years in the study period.

From different types of land use "j", where "j" can be pasture $(\mathrm{Pt})$, crop $(\mathrm{Cp})$, forest $(\mathrm{F})$ or savannah $(\mathrm{Sv})$, the carbon stock $\left(C S_{j}\right)$ is obtained through the sum of carbon stocks of all three compartments (ABGB - Above and Below Ground Biomass $\left(C S_{A B G B_{j}}\right), \mathrm{DOM}$ Dead Organic Matter $\left(C S_{D O M_{j}}\right)$ and SOC - Soil Organic Carbon $\left.\left(C S_{S O C_{j}}\right)\right)$, as shown in equation (4).

$C S_{j}=C S_{S O C_{j}}+C S_{A B G B_{j}}+C S_{D O M_{j}}$

Determination of $C S_{A B G B}$ and $C S_{D O M}$ uses the method proposed by Bernoux et al. (2002), employed in the official Third National Communication of Brazil to the UNFCCC (MSTI, 2016). Phytophysiognomies adopted for the study region are the previous vegetation from the Reference Report (MSTI, 2015b). Determination of carbon stock of soil organic matter for anthropized areas $\left(\mathrm{CS}_{\mathrm{SOC}_{a}}\right)$ combines the classification used in the Reference Report for soil type and vegetation for the studied area (Bernoux et al., 2002; MSTI, 2015b). Since it is not possible to determine the original vegetation for areas currently in use, a weighted average of carbon stock in soil organic matter of natural areas $\left(C_{S O C_{n}}\right)$ is employed with its respective shares of areas used in the studied area $(A \% n)$. This weighted average is multiplied by the relative stock change factors $\left(F_{L U_{a}}, F_{M G_{a}}\right.$ and $\left.F_{I_{a}}\right)$ due to land use, type of management and input, accordingly to equation (5).

$\mathrm{CS}_{\mathrm{SOC}_{a}}=\left[\sum_{n} \mathrm{CS}_{\mathrm{SOC}_{n}} \times A \%_{n}\right] \times F_{L U_{a}} \times F_{M G_{a}} \times F_{I_{a}}$

Equation (6) shows that the total $\mathrm{N}_{2} \mathrm{O}$ emissions due to LUC $\left(L U C_{e N_{2} \mathrm{O}}\right)$ is the sum of direct $\left(L U C_{e N_{2} \mathrm{O} \text { dir }}\right.$ ) and indirect

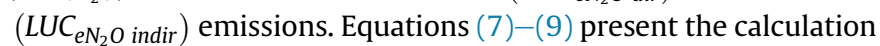
of direct $\mathrm{N}_{2} \mathrm{O}$ emissions and equations (10)-(12) present the calculation of indirect $\mathrm{N}_{2} \mathrm{O}$ emissions.

$$
\begin{aligned}
& L U C_{e_{2} \mathrm{O}}=L U C_{e \mathrm{~N}_{2} \mathrm{O} \text { dir }}+L U C_{\mathrm{eN}_{2} \mathrm{O} \text { indir }} \\
& L U C_{\mathrm{eN}_{2} \mathrm{O} \text { dir }}=D e_{P R P}+D e_{S O M} \\
& D e_{P R P}=\left[N_{C H} \times N_{\text {rate }} \times T A M \times M S_{P R P} \times E F_{3 P R P} \times(44 / 28) \times 298\right] / 2
\end{aligned}
$$

$D e_{S O M}=\frac{\sum_{i}\left[\left(C S_{S_{O C}}-C S_{S O C_{P t}}\right)\right] \times E F_{1} \times(44 / 28) \times 298}{R \times N_{y}}$

$L U C_{\mathrm{eN}_{2} \mathrm{O} \text { indir }}=I e_{\mathrm{PRP}}+I e_{\mathrm{SOM}}$

$$
\begin{aligned}
I e_{P R P}= & {\left[N_{C H} \times N_{\text {rate }} \times T A M \times M S_{P R P} \times\left[\left(\text { Frac }_{G A S M} \times E F_{4}\right)\right.\right.} \\
& \left.\left.+\left(\text { Frac }_{L E A C H-(H)} \times E F_{5}\right)\right] \times(44 / 28) \times 298\right] / 2
\end{aligned}
$$

where $D e_{P R P}\left(\mathrm{~kg} \mathrm{CO}_{2} \mathrm{eq} \mathrm{ha} \mathrm{y}^{-1} \mathrm{y}^{-1}\right)$ is the direct emission due to urine and dung from grazing animals; $N_{C H}$ (animal ha ${ }^{-1}$ ) is the average of the annual stocking rates during the study period, in the area subject to LUC into pasture; $\mathrm{N}_{\text {rate }}\left(\mathrm{kg} \mathrm{N}(\mathrm{kg} \text { animal })^{-1} \mathrm{y}^{-1}\right)$ is the default $\mathrm{N}$ excretion rate; TAM ( $\mathrm{kg}$ animal (animal) $)^{-1}$ ) is the typical animal mass; $M S_{P R P}$ (percentage) is the fraction of total annual $\mathrm{N}$ excretion for each cattle stock in pasture, range and paddock; $E F_{3 P R P}$ ( $\mathrm{kg} \mathrm{N}_{2} \mathrm{O}-\mathrm{N}\left(\mathrm{kg} \mathrm{N}_{\text {input}}\right)^{-1}$ ) is the emission factor for $\mathrm{N}_{2} \mathrm{O}$ emissions from urine and dung $\mathrm{N}$ deposited in pasture, range and paddock by grazing animals; the fraction $44 / 28$ is the rate of $\mathrm{N}_{2} \mathrm{O}$ (emitted) and $\mathrm{N}_{2}$ (stock) molecular masses, used for conversion of $\mathrm{N}_{2} \mathrm{O}-\mathrm{N}$ to $\mathrm{N}_{2} \mathrm{O}$; the factor 298 is the global warning potential for 100 years $\left(\mathrm{GWP}_{100}\right)$ of $\mathrm{N}_{2} \mathrm{O}$, for time horizon of 100 years, from IPCC (2007), used to express the emission result in kilograms of $\mathrm{CO}_{2}$ equivalent; factor 2 is used, since for the calculations, LUC into pasture happens in the middle of the study period; $D e_{S O M}\left(\mathrm{~kg} \mathrm{CO}_{2} \mathrm{eq} \mathrm{ha}{ }^{-1} \mathrm{y}^{-1}\right)$ is the direct emission due to mineralization of nitrogen, in association with loss of soil carbon; $C_{S O C i}\left(\mathrm{~kg} \mathrm{Cha}^{-1}\right)$ is the carbon stock of SOC for types of land use " $i$ "; $C S_{S O C p t}\left(\mathrm{~kg} \mathrm{C} \mathrm{ha}^{-1}\right)$ is the carbon stock of SOC for pasture; $E F_{1}\left(\mathrm{~kg} \mathrm{~N}_{2} \mathrm{O}-\mathrm{N}(\mathrm{kg} \mathrm{N})^{-1}\right)$ is the emission factor for $\mathrm{N}_{2} \mathrm{O}$ from nitrogen inputs; $R\left(\mathrm{~kg} \mathrm{C}(\mathrm{kg} \mathrm{N})^{-1}\right)$ is $\mathrm{C}: \mathrm{N}$ ratio of the SOM; $N_{y}(\mathrm{y})$ is the number of years in the study period; $I e_{P R P}(\mathrm{~kg} \mathrm{CO} 2 \mathrm{eq}$ $\mathrm{ha}^{-1} \mathrm{y}^{-1}$ ) is the indirect emission due to urine and dung of animals during grazing; Frac $_{\text {GASM }}$ (percentage) is the fraction of urine and dung $\mathrm{N}$ deposited in pasture by grazing animals; $\mathrm{FE}_{4}\left(\mathrm{~kg} \mathrm{~N} \mathrm{~N}_{2} \mathrm{O}-\mathrm{N}(\mathrm{kg}\right.$ of $\mathrm{N}$ additions $)^{-1}$ ) is the emission factor for $\mathrm{N}_{2} \mathrm{O}$ emissions from atmospheric deposition of $\mathrm{N}$ on soil and water surfaces; Frac $\mathrm{CEACH}_{\mathrm{L}-}$ $(H)$ (percentage) is the fraction of all $\mathrm{N}$ added to or mineralized in managed soils in regions where losses from leaching/runoff occur; $E F_{5}\left(\mathrm{~kg} \mathrm{~N}_{2} \mathrm{O}-\mathrm{N}(\mathrm{kg} \text { of } \mathrm{N} \text { leached and runoff })^{-1}\right)$ is the emission factor for $\mathrm{N}_{2} \mathrm{O}$ emissions from nitrogen leaching and runoff; and IesOM $(\mathrm{kg}$ $\mathrm{CO}_{2} \mathrm{eq} \mathrm{ha} \mathrm{ha}^{-1} \mathrm{y}^{-1}$ ) is the indirect emission due to mineralization of nitrogen, in association with loss of soil carbon.

\subsection{Method for GHG emissions assessment of the beef tallow biodiesel production cycle}

Calculations for GHG emissions from the beef tallow biodiesel production cycle are given by equation (13), where three phases are considered: cattle farming, starting with cow pregnancy, going through calf weaning, rearing and finishing; live animal transport to slaughterhouse/packing plant; and the industrial phase, which includes animal slaughtering, rendering, tallow transportation and finally the transesterification process. The sum of all these emissions is multiplied by the ratio between the average time in which the area was used as pasture $\left(Y_{g}\right)$ and the number of the years of the study period $\left(\mathrm{N}_{\mathrm{y}}\right)$. $\mathrm{Y}_{\mathrm{g}}$ is calculated dividing by two the number of years of the study period minus one, since in the year LUC happens, the given area is not used as pasture due to soil preparation practices.

$B D_{e}=\left(\frac{Y_{g}}{N_{y}}\right) \times\left(C F_{e}+T P c_{e}+S R_{e}+T P t_{e}+T r_{e}\right)$

where $B D_{e}\left(\mathrm{~kg} \mathrm{CO}_{2} \mathrm{eq} \mathrm{ha} \mathrm{a}^{-1} \mathrm{y}^{-1}\right)$ is annual emission from biodiesel production; $C_{e}\left(\mathrm{~kg} \mathrm{CO} \mathrm{CO}_{2} \mathrm{eq} \mathrm{ha}^{-1} \mathrm{y}^{-1}\right)$ is the annual emission per head due to enteric fermentation, manure management in cattle

$I e_{S O M}=\frac{\sum_{i}\left[\left(C_{S C_{i}}-C S_{S O C_{P t}}\right)\right] \times \operatorname{Frac}_{L E A C H-(H)} \times E F_{5} \times(44 / 28) \times 298}{R \times N_{y}}$ 


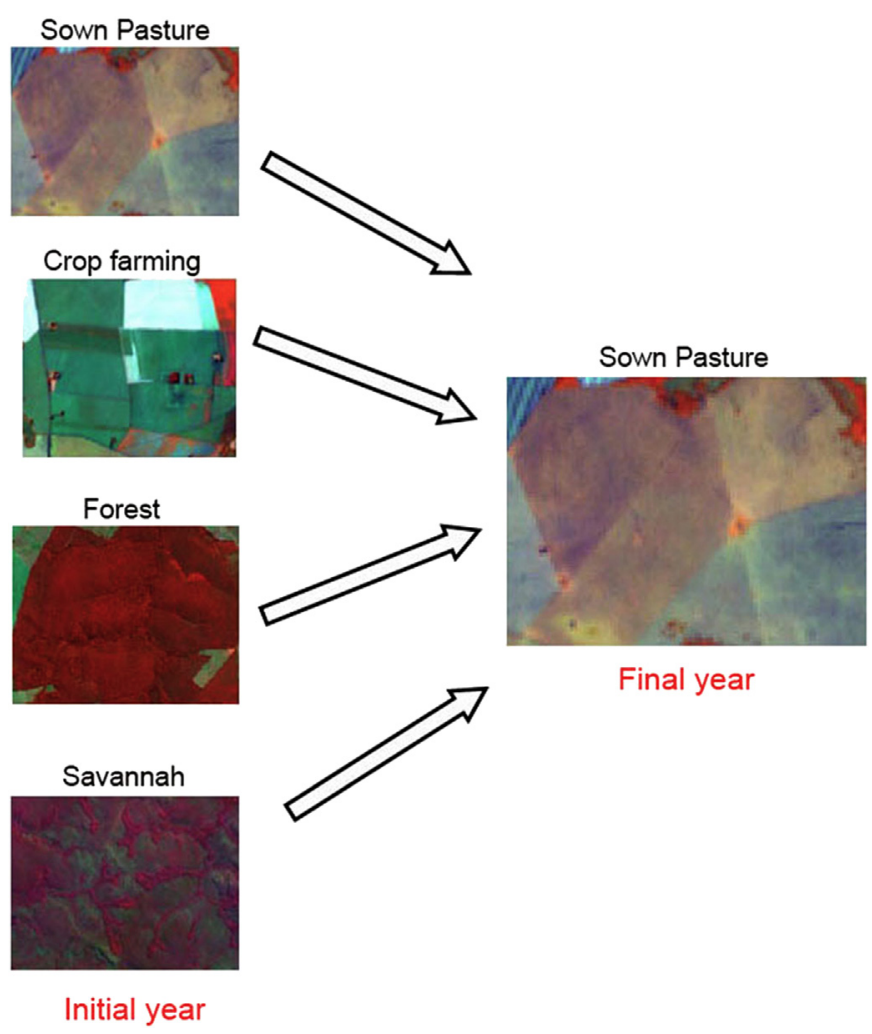

Fig. 6. Satellite imagery interpretation to estimate land use change.

farming; $T P c_{e}\left(\mathrm{~kg} \mathrm{CO} \mathrm{CO}_{2} \mathrm{ha}^{-1} \mathrm{y}^{-1}\right)$ is the annual emission from cattle transportation; $S R_{e}\left(\mathrm{~kg} \mathrm{CO}_{2} \mathrm{eq} \mathrm{ha} \mathrm{h}^{-1} \mathrm{y}^{-1}\right)$ is the annual emission from the slaughtering and rendering phase; $\mathrm{TPt}_{e}\left(\mathrm{~kg} \mathrm{CO} \mathrm{CO}_{2} \mathrm{eq}\right.$ $\left.\mathrm{ha}^{-1} \mathrm{y}^{-1}\right)$ is the annual emission from tallow transportation; and $\operatorname{Tr}_{e}\left(\mathrm{~kg} \mathrm{CO} \mathrm{CO}_{2} \mathrm{eq} \mathrm{ha} \mathrm{y}^{-1} \mathrm{y}^{-1}\right)$ is the annual emission from the transesterification phase.

\subsubsection{Method for calculating GHG emissions from the cattle farming phase}

GHG emissions from the cattle farming consider enteric fermentation and waste management, shown in equation (14). This item accounts for emissions from breeding cows during pregnancy and suckling; emissions from breeding bulls; emissions from young animals, after weaning until end of rearing; and emissions from adult animals during finishing until slaughter. Since the local cattle systems are generally extensive, emissions due to cattle feeding and management are minimal and are not counted. cows; $E F_{r}(\mathrm{~kg} \mathrm{CO} \text { eq (head) })^{-1} \mathrm{y}^{-1}$ ) is the annual emission factor of rearing due to enteric fermentation and manure management; $t_{r}$ (months) is the time of rearing grazing; $\mathrm{Sr}_{r}$ (head ha ${ }^{-1}$ ) is the stocking rate during rearing; $\left.E F_{a}(\mathrm{~kg} \mathrm{CO} \text { eq (head) })^{-1} \mathrm{y}^{-1}\right)$ is the annual emission factor of adults due to enteric fermentation and manure management; $t_{a}$ (months) is the time of adult grazing; $\mathrm{Sr}_{a}$ (head ha $\mathrm{h}^{-1}$ ) is the stocking rate of adults; $t_{b}$ (months) is the time of bulls grazing; and $S r_{b}$ (head ha ${ }^{-1}$ ) is the stocking rate of bulls.

\subsection{Inventory allocation methods}

Multi-output processes need to adopt inventory allocation methods that allow distributing impacts among main products that will continue in the stream of the production chain under analysis, as well co-products and byproducts. According to definitions from ISO 14040:2006 and ISO 14044:2006, co-products, byproducts and wastes are outputs that come from the same processing unit that originates the main product (ISO, 2006a; ISO, 2006b). Based on Horne and Matthews (2004), Annex 11 of 35th Meth Panel Report (UNFCCC, 2008), co-products are products that have value similar to the main product, byproducts have value lower than the main product and residues/wastes have little or no value.

Allocation is mandatory when analyzing tallow biodiesel production since the other products present, like beef and hides, are the main drivers of the chain and are economically more important than the biodiesel itself. The allocation approaches adopted in this work are mass allocation and three of the four other types defined in the Methodologies Panels of the Clean Development Mechanism (CDM) of UNFCCC (UNFCCC, 2008). The following approaches are adopted: (1) allocation by mass, (2) allocation by market value, (3) allocation by energy content and (4) no allocation. Allocation by mass is the simplest approach, which uses the mass share of the main product and the other outputs of the production stage. In allocation by market value, the mass of each product is multiplied by the respective market price per unit of mass and then divided by the sum of products between masses and market values of all outputs. "The market prices may be either monitored ex post or be determined once for the crediting period. This rule can be applied only if transparent and reliable information on market prices is available" (UNFCCC, 2008). In energy allocation, the emissions are apportioned using the heat values of products. This method is not suitable for processes where some output cannot be used as fuel (Horne and Matthews, 2004; UNFCCC, 2008). The "no allocation" alternative is a conservative approach where all emissions are assigned to the main product.

\section{Premises, input data and results}

\subsection{Area and period of study}

$C F_{e}=\frac{\left(E F_{b c} \times\left(t_{p}+t_{s}\right) \times S r_{b c}\right)+\left(E F_{r} \times t_{r} \times S r_{r}\right)+\left(E F_{a} \times t_{a} \times S r_{a}\right)+\left(E F_{a} \times t_{b} \times S r_{b}\right)}{t_{p}+t_{s}+t_{b}+t_{r}+t_{a}}$

where $C_{e}\left(\mathrm{~kg} \mathrm{CO}_{2} \mathrm{eq} \mathrm{ha}{ }^{-1} \mathrm{y}^{-1}\right)$ is the annual emission per slaughtered head due to enteric fermentation, manure management and annual emission due to energy used in cattle farming to manage each animal; $\left.E F_{b c}\left(\mathrm{~kg} \mathrm{CO}_{2} \mathrm{eq} \text { (head) }\right)^{-1} \mathrm{y}^{-1}\right)$ is the annual emission factor of breeding cows due to enteric fermentation and manure management; $t_{p}$ (months) is the pregnancy time; $t_{s}$ (months) is the suckling time; $S r_{b c}$ (head $\mathrm{ha}^{-1}$ ) is the stocking rate of breeding
The study area is the Dourados micro-region (DMR), in Mato Grosso do Sul state (MS), an important and representative farming area in Brazil. This state is the third largest soybean producer in Brazil and has also the third largest cattle slaughter in Brazil. When considering the global importance of Brazil as second largest exporter of these two products, one can realize the importance of Mato Grosso do Sul in this scenario. In turn, the DMR shows strong 
Table 1

Land use change (LUC) to pasture from 1993 to 2013 in the Dourados micro-region, Mato Grosso do Sul state, Brazil.

\begin{tabular}{llll}
\hline LUC & Area (ha) & Share & LUC area proportion \\
\hline Crop to pasture & 19,652 & $1.82 \%$ & $11.48 \%$ \\
Savannah to pasture & 138,122 & $12.80 \%$ & $80.69 \%$ \\
Forest to pasture & 13,401 & $1.24 \%$ & $7.83 \%$ \\
No LUC & 907,792 & $84.14 \%$ & - \\
\hline Total pasture area in 2013 & $1,078,967$ & $100.00 \%$ & $100.00 \%$ \\
\hline
\end{tabular}

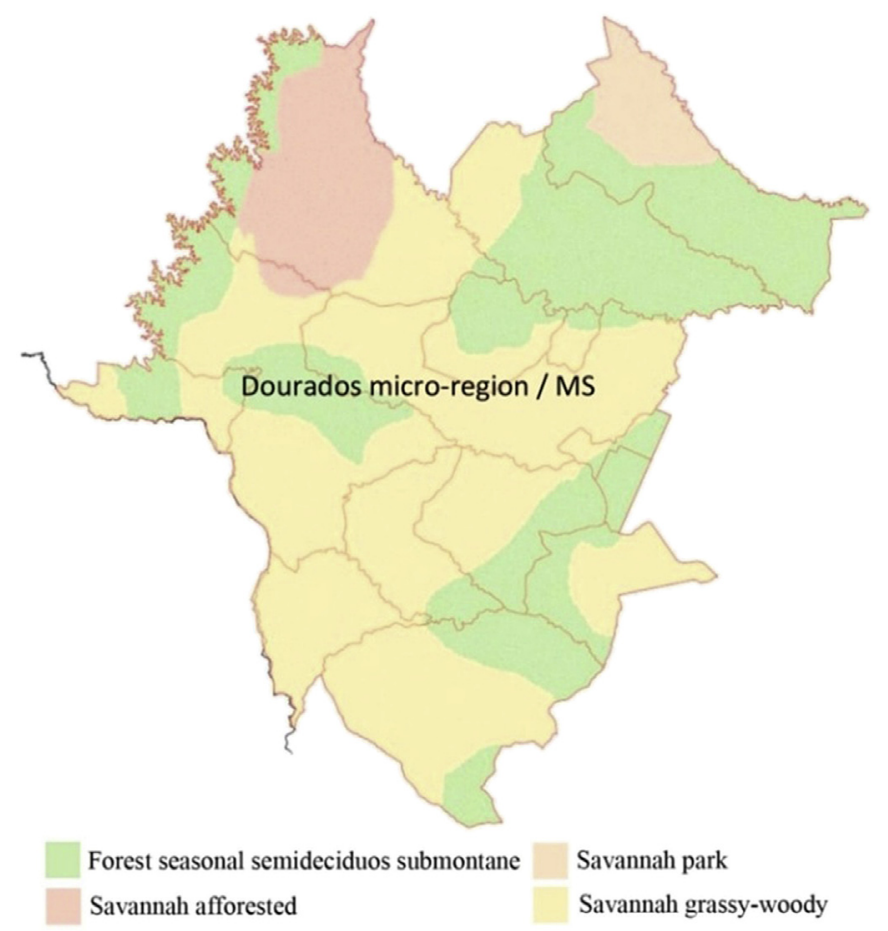

Fig. 7. Previous phytophysiognomies of Dourados micro-region, Mato Grosso do Sul state, Brazil.

Source: Adapted from MSTI (2015b).

expansion of crop farming over sown pastures (Esteves et al., 2016). The DMR is the largest soybean producer in MS and was ranked as fourth in number of cattle slaughtered in 2014. The period studied to estimate GHG emissions due to LUC ranges from 1993 to 2013, when reasonably good images are available. The reference year for cattle slaughter and biodiesel production is 2014, to incorporate the last LUC data of the studied period.

\subsection{Identification of LUC areas}

From DMR total area in 2013 (3,731,875 ha), 29\% was used as pastures, corresponding to $1,078,966$ ha and of the $15.8 \%$ where
LUC occurred, $88.5 \%$ was from natural areas (savannah and forest) to pasture (Table 1 ).

\subsection{Calculation of GHG emissions due to LUC}

To determine carbon stock of $\mathrm{ABGB}$ ( $\mathrm{CS}_{\mathrm{ABGB}}$ ) plus carbon stock of $\mathrm{DOM}\left(\mathrm{CS}_{\mathrm{DOM}}\right)$ of natural areas, previous phytophysiognomies of the study area are identified, as presented in Fig. 7.

Table 2 shows the savannah and forest shares of previous phytophysiognomies in the DMR and carbon stocks on ABGB plus DOM $\left(\mathrm{CS}_{\mathrm{ABGB}}+\mathrm{CS}_{\mathrm{DOM}}\right)$. The last column shows carbon stocks weighted through their relative share of the total. The sum of values in this last column represents the average ABGB plus DOM stocks in savannah (Sv) and forest (F) (CS $\mathrm{CSBGBV}_{\mathrm{B}}+\mathrm{CS}_{\mathrm{DOMSv}}$ and $\left.\mathrm{CS}_{\mathrm{ABGBF}}+\mathrm{CS}_{\mathrm{DOMF}}\right)$.

Carbon stock of ABGB plus DOM $\left(\mathrm{CS}_{\mathrm{ABGB}}+\mathrm{CS}_{\mathrm{DOM}}\right)$ for crop farming and pastures, used in this work are $5000 \mathrm{~kg} \mathrm{C}^{-1}$ and $7570 \mathrm{~kg} \mathrm{C} \mathrm{ha}^{-1}$ (IPCC, 2003). The predominant soil class for the study area is S2 (low reactive latosol with clay) for vegetation, predominance of categories V5 (semideciduous seasonal forest) and V9 (savannah) (Bernoux et al., 2002). The combination of this information results in $44,300 \mathrm{~kg} \mathrm{Cha}^{-1}$ and $43,100 \mathrm{~kg} \mathrm{C} \mathrm{ha}^{-1}$ of SOC stock for forest $\left(\mathrm{CS}_{\mathrm{SOCF}}\right)$ and savannah $\left(\mathrm{CS}_{\mathrm{SOCSv}}\right)$ (MSTI, 2015b). For determination of $\mathrm{CS}_{\mathrm{SOC}}$ for anthropized areas, equation (5) is used. $\mathrm{CS}_{\mathrm{SOC}}$ are applied to savannah and forests areas $\left(43,100 \mathrm{~kg} \mathrm{C} \mathrm{ha}^{-1}\right.$ and $44,300 \mathrm{~kg} \mathrm{C} \mathrm{ha}^{-1}$ ) and its respective rates of occupation (62.8\% and $37.2 \%)$ from Table 2 . Stock change factors $\left(F_{L U}, F_{M G}\right.$ and $\left.F_{I}\right)$ are $0.58,1.16$ and 0.91 for crops and 1.00, 0.97 and 1.00 for pasture. Table 3 shows carbon stocks per compartment for the different types of land use in the study area.

Table 4 shows herd composition data stocking rates by animal category in the DMR. Herd data were obtained from the Animal and Plant Health Protection Agency of Mato Grosso do Sul State (IAGRO, 2016). Stocking rates were obtained by dividing the number of animals of each category by the total pasture area of the DMR $(1,078,967 \mathrm{ha})$. The sum of all stocking rates gives $N_{C H}=1.489$ animal ha ${ }^{-1}$ (Table 4). Breeding cows are considered a separate category due to different aspects of their grazing management.

TAM is calculated based on detailed herd data from IAGRO (2016) and average weight suggested by the Brazilian Agricultural Research Corporation (EMBRAPA, 2016), as presented in Table A1 (Supplementary Material). Slaughtering age for extensive systems in the area is often reached in 36 months. TAM obtained from local data is $301.76 \mathrm{~kg}$ per animal, which is a figure very close to the $305 \mathrm{~kg}$ per animal indicated by the Guidelines for National Greenhouse Gas Inventories (IPCC, 2006). Using these numbers in equations (8) and (11), and $N_{\text {rate }}=0.1314 \mathrm{~kg} \mathrm{~N}(\mathrm{~kg} \text { animal })^{-1} \mathrm{y}^{-1}$ (IPCC, 2006), $M S_{P R P}=100 \%$ (since this work considers exclusively extensive systems), $E F 3_{P R P}=0.02 \mathrm{~kg} \quad \mathrm{~N}_{2} \mathrm{O}-\mathrm{N} \quad\left(\begin{array}{ll}\mathrm{kg} & \mathrm{N}\end{array}\right)^{-1}$, Frac $_{G A S M}=0.20, E F_{4}=0.01$, Frac $_{L E A C H-(H)}=0.30, E F_{5}=0.0075($ IPCC, 2006), the following are obtained: $D e_{P R P}=276.41 \mathrm{~kg} \mathrm{CO}_{2} \mathrm{eq} \mathrm{ha}^{-1}$ $\mathrm{y}^{-1}$ and $I_{P R P}=4692.00 \mathrm{~kg} \mathrm{CO}_{2} \mathrm{eq} \mathrm{ha} \mathrm{h}^{-1} \mathrm{y}^{-1}$.

The annual $\mathrm{CO}_{2}$ emissions per hectare due to $\mathrm{LUC}\left(\mathrm{LUCe}_{\mathrm{CO}_{2}}\right)$ in

Table 2

Previous phytophysiognomies in Dourados micro-region, Mato Grosso do Sul State, Brazil.

\begin{tabular}{|c|c|c|c|c|}
\hline & Phytophysiognomies & $\%$ & $\mathrm{CS}_{\mathrm{ABGB}}+\mathrm{CS}_{\mathrm{DOM}}\left(\mathrm{kg} \mathrm{C} \mathrm{ha}^{-1}\right)$ & Weighed by \% \\
\hline Sa & Savannah afforested & 8.78 & 39,920 & 5581 \\
\hline Sp & Savannah park & 3.46 & 24,650 & 1358 \\
\hline \multirow[t]{2}{*}{$\mathrm{Sg}$} & Savannah grassy-woody & 50.56 & 18,490 & 14,886 \\
\hline & Total savannah & 62.80 & $\mathrm{CS}_{\text {ABGBSv }}+\mathrm{CS}_{\text {DOMSv }}\left(\mathrm{kg} \mathrm{Cha}^{-1}\right)=21,825$ & \\
\hline \multirow[t]{2}{*}{ Fs } & Seasonal semideciduos submontane forest & 37.20 & 87,550 & 87,550 \\
\hline & Total forest & 37.20 & $\mathrm{CS}_{\mathrm{ABGBF}}+\mathrm{CS}_{\mathrm{DOMF}}\left(\mathrm{kg} \mathrm{C} \mathrm{ha}^{-1}\right)=87,550$ & \\
\hline
\end{tabular}


Table 3

Carbon stocks (CS) for different land uses in the Dourados micro-region, Mato Grosso do Sul state, Brazil.

\begin{tabular}{|c|c|c|c|}
\hline Land Use & $\mathrm{CS}_{\mathrm{ABGB}}+\mathrm{CS}_{\mathrm{DOM}}\left(\mathrm{kg} \mathrm{C} \mathrm{ha}^{-1}\right)$ & $\mathrm{CS}_{\mathrm{SOC}}\left(\mathrm{kg} \mathrm{C} \mathrm{ha}{ }^{-1}\right)$ & $\mathrm{CS}_{\mathrm{i}}\left(\mathrm{kg} \mathrm{Ch \textrm {ha } ^ { - 1 } )}\right.$ \\
\hline Tropical forest $(\mathrm{i}=\mathrm{F})$ & 87,550 & 44,300 & 131,850 \\
\hline Savannah $(\mathrm{i}=\mathrm{Sv})$ & 21,825 & 43,100 & 64,925 \\
\hline Pasture $(\mathrm{i}=\mathrm{Pt})$ & 7570 & 42,240 & 49,810 \\
\hline Crop $(\mathrm{i}=\mathrm{Cp})$ & 5000 & 26,661 & 31,661 \\
\hline
\end{tabular}

Table 4

Herd per animal category and their respective stocking rates for 2013 , in the Dourados micro-region, Mato Grosso do Sul state, Brazil.

\begin{tabular}{llll}
\hline & Herd (head) & Share & Stocking rate (head ha ${ }^{-1}$ ) \\
\hline Breeding cows & 558,572 & $35 \%$ & $\mathrm{Sr}_{\mathrm{bc}}=0.518$ \\
Bulls & 15,959 & $1 \%$ & $\mathrm{Sr}_{\mathrm{b}}=0.015$ \\
Rearing & 386,089 & $24 \%$ & $\mathrm{Sr}_{\mathrm{r}}=0.358$ \\
Adults & 645,548 & $40 \%$ & $\mathrm{Sr}_{\mathrm{a}}=0.598$ \\
\hline Total & $1,606,167$ & & $\mathrm{~N}_{\mathrm{CH}}=1.489$ \\
\hline
\end{tabular}

the area are obtained by applying the values from Table 3 in equation (3), considering $N_{y}=20$ years (Table 5).

From Table 3 and equations ( 9 ) and (12), considering $E F_{1}=0.01$, $\mathrm{R}=15 \mathrm{C} \mathrm{N}^{-1}, \operatorname{Frac}_{\text {LEACH- }(H)}=0.30, E F_{5}=0.0075$ (IPCC, 2006), the values of DesOM and IesOM for different LUCs are obtained. Table 5 summarizes the emissions plots and total annual emissions due to LUC, expressed in $\mathrm{kg} \mathrm{CO}$ eq per hectare.

In last row of Table 5, emissions due to changes from crop to pasture present negative values in the items that depend on carbon stock variation $\left(\mathrm{LUCe}_{\mathrm{CO} 2}, D e_{\mathrm{SOM}}, \mathrm{I}_{\mathrm{SOM}}\right.$ ), because the carbon stock in land used for crops is less than for land used as pasture. Note in equations (3) (9) and (12) that the difference between the carbon stock of current and previous uses determines the sign of the result, so if this difference is negative, the emissions are negative. For these items, the negative emissions value represents a GHG sink, which ultimately means an environmental benefit. Despite this, total emissions from LUC $\left(L U C e_{(C p-P t)}\right)$, which is the sum of all items (equation (2), (6), (7) and (10)), has positive value because the sum of emissions that depend on cattle management $\left(D e_{P R B} I e_{P R P}\right)$ outweigh the subtotal of items with negative emissions.

\subsection{GHG emissions from the cattle farming phase}

Since cattle farming in the studied area is predominantly extensive, with relatively low use of manufactured inputs, this work considers only enteric emissions from cattle and manure management. Table 6 shows the phases of the local cattle husbandry cycle with duration of each category in animal life, as well as GHG emissions from enteric fermentation and waste management (columns 4 and 5), obtained from the Reference Report of Agriculture Sector of the Third National Communication of Brazil to the United Nations Framework Convention on Climate Change (MSTI, 2015a). Summation of these emissions multiplied by 25 , which is the $\mathrm{GWP}_{100}$ for $\mathrm{CH}_{4}$ (methane) (IPCC, 2007), gives the emission factors by animal category. Applying emission factors, periods of each husbandry phase and stocking rates (Table 4), in equation (13), yields $\mathrm{CF}_{\mathrm{e}}=527.93 \mathrm{~kg} \mathrm{CO}_{2} \mathrm{eq} \mathrm{ha} \mathrm{h}^{-1} \mathrm{y}^{-1}$.

\subsection{Transport GHG emissions}

Official data on cattle transport for slaughter from the DMR were also obtained from IAGRO (2016). The data show how many heads of cattle from each municipality were sent to each slaughterhouse every year. Animal categories given are males and females with age categories: 13 to 24; 25 to 36 and over 36 months (Table A2, Supplementary Material).

In order to obtain the total live weight carried by category, the number of heads is multiplied by the average weight of the category (Table A1, Supplementary Material), resulting in a total of

Table 5

Annual $\mathrm{CO}_{2}$ and $\mathrm{N}_{2} \mathrm{O}$ emissions per hectare due to land use change (LUC).

\begin{tabular}{|c|c|c|c|c|c|c|c|c|}
\hline \multirow[t]{2}{*}{ Previous use } & \multirow[t]{2}{*}{ Current use } & \multirow{2}{*}{$\frac{\mathrm{CS}_{\mathrm{i}}-\mathrm{CS}_{\mathrm{Pt}}^{\mathrm{a}}}{\left(\mathrm{kg} \mathrm{Cha}{ }^{-1}\right)}$} & LUCe $_{\mathrm{CO} 2}{ }^{\mathrm{b}}$ & $\mathrm{De}_{\mathrm{PRP}}{ }^{\mathrm{c}}$ & $\mathrm{De}_{\mathrm{SOM}}{ }^{\mathrm{d}}$ & $\mathrm{Ie}_{\mathrm{PRP}}{ }^{\mathrm{e}}$ & le $_{\text {SOM }}{ }^{f}$ & LUCe $_{(\mathrm{i}-\mathrm{Pt})^{g}}{ }^{g}$ \\
\hline & & & \multicolumn{6}{|c|}{$\left(\mathrm{kg} \mathrm{CO}_{2}\right.$ eq ha $\left.{ }^{-1} \mathrm{y}^{-1}\right)$} \\
\hline Forest $(\mathrm{i}=\mathrm{F})$ & Pasture (Pt) & $82,039.99$ & $15,040.67$ & 276.41 & 32.16 & 4692.00 & 7.23 & $20,048.47$ \\
\hline Savannah $(\mathrm{i}=\mathrm{Sv})$ & Pasture (Pt) & $15,115.49$ & 2771.17 & 276.41 & 13.42 & 4692.00 & 3.03 & 7756.04 \\
\hline Crop $(\mathrm{i}=\mathrm{Cp})$ & Pasture (Pt) & $-18,148.81$ & -3327.28 & 276.41 & -243.18 & 4692.00 & -55.08 & 1342.87 \\
\hline
\end{tabular}

a Difference between accumulated carbon stock per hectare in areas where LUC from forest, savannah or crop farming to pasture happened.

b Annual $\mathrm{CO}_{2}$ emission per hectare due to LUC.

c Annual direct emission of $\mathrm{N}_{2} \mathrm{O}$ due to urine and dung from grazing animals.

d Annual direct emission of $\mathrm{N}_{2} \mathrm{O}$ due to mineralization of nitrogen, in association with loss of soil carbon.

e Annual indirect emission of $\mathrm{N}_{2} \mathrm{O}$ due to urine and dung from grazing animals.

f Annual indirect emission of $\mathrm{N}_{2} \mathrm{O}$ due to mineralization of $\mathrm{N}$ associated with loss of soil organic matter.

$g$ Total annual $\mathrm{CO}_{2}$ and $\mathrm{N}_{2} \mathrm{O}$ emission due to LUC from other uses (i) to pasture.

Table 6

Greenhouse gases emissions from enteric fermentation and waste management for cattle husbandry cycle in Brazil.

\begin{tabular}{|c|c|c|c|c|c|}
\hline & Phases & $\begin{array}{l}\text { Time } \\
\text { (months) }\end{array}$ & $\begin{array}{l}\text { Enteric Fermentation } \\
\left(\mathrm{kg} \mathrm{CH}_{4} \text { head }^{-1} \mathrm{y}^{-1}\right)\end{array}$ & $\begin{array}{l}\text { Manure Management } \\
\left(\mathrm{kg} \mathrm{CH}_{4} \text { head }^{-1} \mathrm{y}^{-1}\right)\end{array}$ & $\begin{array}{l}\text { Emission Factors } \\
\left(\mathrm{kg} \mathrm{CO}_{2} \text { eq head }{ }^{-1} \mathrm{y}^{-1}\right)\end{array}$ \\
\hline Breeding cow & $\begin{array}{l}\text { pregnancy } \\
\text { suckling }\end{array}$ & $\begin{array}{l}t_{p}=9 \\
t_{s}=7\end{array}$ & 62.0 & 1.2 & $\mathrm{EF}_{\mathrm{bc}}=1580.0$ \\
\hline Bull & - & $t_{b}=12$ & 51.0 & 1.3 & $\mathrm{EF}_{\mathrm{b}}=1307.5$ \\
\hline Adult & grazing & $t_{a}=16$ & 51.0 & 1.3 & $\mathrm{EF}_{\mathrm{a}}=1307.5$ \\
\hline Rearing & grazing & $\mathrm{t}_{\mathrm{r}}=16$ & 40.0 & 0.8 & $\mathrm{EF}_{\mathrm{r}}=1020.0$ \\
\hline
\end{tabular}


Table 7

Inputs necessary for slaughtering and rendering process and respective emissions in Brazil.

\begin{tabular}{|c|c|c|c|c|c|}
\hline \multirow[b]{2}{*}{ Water } & \multicolumn{2}{|c|}{ Per kg of slaughtered animal } & \multicolumn{2}{|c|}{ Per hectare of pasture } & \multirow{2}{*}{$\begin{array}{l}\text { Emission }\left(\mathrm{kg} \mathrm{CO}_{2} \mathrm{eq} \mathrm{ha}^{-1}\right) \\
0.00534\end{array}$} \\
\hline & 4.4444 & $\mathrm{~L}$ & 424.0940 & $\mathrm{~L}$ & \\
\hline Firewood & 0.1037 & $\mathrm{~kg}$ & 9.8953 & $\mathrm{~kg}$ & 0.62700 \\
\hline Fuel oil & 0.0141 & $\mathrm{~kg}$ & 1.3426 & $\mathrm{~kg}$ & 0.93400 \\
\hline Diesel & 0.0011 & $\mathrm{~L}$ & 0.1088 & $\mathrm{~L}$ & 0.08450 \\
\hline Electricity & 0.0195 & $\mathrm{kWh}$ & 1.8625 & kWh & 1.50000 \\
\hline \multicolumn{5}{|c|}{ Total emission $\left(\mathrm{kg} \mathrm{CO}_{2} \mathrm{eq} \mathrm{ha}{ }^{-1}\right)$} & 3.15084 \\
\hline
\end{tabular}

Table 8

Inputs necessary for the transesterification process and respective emissions in Brazil.

\begin{tabular}{|c|c|c|c|c|c|}
\hline & \multicolumn{2}{|c|}{ Per cubic meter of tallow } & \multicolumn{2}{|c|}{ Per hectare of pasture } & \multirow{2}{*}{$\begin{array}{l}\text { Emission } \\
\left(\mathrm{kg} \mathrm{CO}_{2} \mathrm{eq} \mathrm{ha}^{-1}\right) \\
0.070200\end{array}$} \\
\hline Firewood & 0.3907 & $\mathrm{~m}^{3}$ & 0.00185 & $\mathrm{~m}^{3}$ & \\
\hline Electricity & 52.1575 & $\mathrm{kWh}$ & 0.24747 & $\mathrm{kWh}$ & 0.200000 \\
\hline Water & 18.3903 & $\mathrm{~kg}$ & 0.08726 & $\mathrm{~kg}$ & 0.000001 \\
\hline Sodium hydroxide & 8.7955 & $\mathrm{~kg}$ & 0.04173 & $\mathrm{~kg}$ & 0.081900 \\
\hline Phosphoric acid & 3.0008 & $\mathrm{~kg}$ & 0.01424 & $\mathrm{~kg}$ & 0.022200 \\
\hline Methanol & 0.1300 & $\mathrm{~m}^{3}$ & 0.00062 & $\mathrm{~m}^{3}$ & 0.424000 \\
\hline Sodium methylate & 11.2606 & $\mathrm{~kg}$ & 0.05343 & $\mathrm{~kg}$ & 0.122000 \\
\hline Hydrochloric acid & 5.1212 & $\mathrm{~kg}$ & 0.02430 & $\mathrm{~kg}$ & 0.047100 \\
\hline \multicolumn{3}{|c|}{ Total emission $\left(\mathrm{kg} \mathrm{CO}_{2} \mathrm{eq} \mathrm{ha}{ }^{-1}\right)$} & & & 0.967401 \\
\hline
\end{tabular}

102,957.3 metric tons. A central point of the grazing areas of each municipality is adopted for calculating transport distances, considering the shortest paths over local paved roads. With distance data obtained from Table A2 (Supplementary Material), a total of $16,615,895.18$ metric ton-kilometers $(\mathrm{t} \mathrm{km})$ is obtained, which, divided by the total pasture area in 2013 (1,078,967 ha), gives $15.40 \mathrm{t} \mathrm{km} \mathrm{ha}^{-1}$. Entering this number in SIMAPRO ${ }^{\circledR}$ yields $T_{P} c_{e}=6.1 \mathrm{~kg} \mathrm{CO}_{2} \mathrm{eq} \mathrm{ha}{ }^{-1} \mathrm{y}^{-1}$ for emission from the live cattle transport phase.

For a total of $102,957,300 \mathrm{~kg}$ (live weight) of slaughtered cattle from the DMR (Table A2, Supplementary Material), and an average tallow yield of $4.5 \%$, the total tallow production is $4,633,079 \mathrm{~kg}$. Considering a density of $905 \mathrm{~kg} / \mathrm{m}^{3}$ (Firestone, 2006), the total tallow produced in the DMR is $5119.42 \mathrm{~m}^{3}$. This represents $11.67 \%$ of the total tallow processed into biodiesel in Mato Grosso do Sul state $\left(43,855.92 \mathrm{~m}^{3}\right)$.

This $5119.42 \mathrm{~m}^{3}$ of tallow is carried by truck to Delta, in Rio Brilhante municipality, the only tallow processing facility in the state, for a total of $877,965.80 \mathrm{t} \mathrm{km}$ from the different slaughterhouses and the transesterification unit. In order to obtain a figure per hectare, this total is divided by the total area of pasture in the DMR in $2013(1,078,966 \mathrm{ha})$, obtaining $0.81 \mathrm{t} \mathrm{km} \mathrm{ha}{ }^{-1}$. Inputting this data in SIMAPRO ${ }^{\circledR}$ yields $T_{P t}=0.321 \mathrm{~kg} \mathrm{CO}_{2} \mathrm{eq} \mathrm{ha}{ }^{-1} \mathrm{y}^{-1}$ for emission from the tallow transport phase.

\subsection{Emissions from the processing phase}

Table 7 presents mass and energy entries and emissions from the slaughtering and rendering phase. Slaughtering and rendering processes are integrated, so there is no transport of slaughter products for rendering somewhere else. Entries are given in kilograms of live weight of slaughtered animal and per hectare of pasture, considering a yield of $95.42 \mathrm{~kg}$ of slaughtered animal per hectare (Table A2, Supplementary Material). The resulting emissions are obtained by entering figures per hectare in SIMAPRO ${ }^{\circledR}$.

The inputs for the transesterification phase are presented in Table 8 , measured per cubic meter of tallow and per hectare of pasture, considering a tallow yield of $4.74 \mathrm{~L}$ per hectare $\left(\mathrm{L} \mathrm{ha}^{-1}\right)$ (Table A2, Supplementary Material). Emissions are derived by applying inputs per hectare in SIMAPRO ${ }^{\circledR}$.

Table 9

Outputs from slaughtering and rendering process, its mass, market value and energy content and respective allocation factors.

\begin{tabular}{|c|c|c|c|c|c|c|}
\hline & \multirow{2}{*}{$\frac{\text { Mass }^{\mathrm{a}}}{(\mathrm{kg})}$} & \multirow{2}{*}{$\frac{\text { Market Value }^{\mathrm{a}}}{(\mathrm{US} \$ / \mathrm{kg})}$} & \multirow{2}{*}{$\frac{\text { Energy }}{(\mathrm{MJ} / \mathrm{kg})}$} & \multicolumn{3}{|c|}{ Allocation factors } \\
\hline & & & & $\overline{\mathrm{AF}_{\mathrm{sr}}[\mathrm{m}]^{\mathrm{b}}}$ & $\mathrm{AF}_{\mathrm{sr}}[\mathrm{v}]^{\mathrm{C}}$ & $\mathrm{AF}_{\mathrm{sr}}[\mathrm{e}]^{\mathrm{d}}$ \\
\hline Meat (beef + organs and entrails) & 236.52 & 3.62 & $5.64^{\mathrm{e}}$ & $69.79 \%$ & $93.07 \%$ & $48.12 \%$ \\
\hline Hides & 44.55 & 0.82 & $1.13^{\mathrm{f}}$ & $13.14 \%$ & $3.96 \%$ & $1.82 \%$ \\
\hline MBM & 37.60 & 0.30 & $15.70^{g}$ & $11.09 \%$ & $1.24 \%$ & $21.31 \%$ \\
\hline Tallow & 20.25 & 0.79 & $39.33^{e}$ & $5.97 \%$ & $1.73 \%$ & $28.75 \%$ \\
\hline Gastric-intestinal contents & 67.50 & - & - & - & - & - \\
\hline Blood & 22.50 & - & - & - & - & - \\
\hline Losses & 21.08 & - & - & - & - & - \\
\hline Totals & 450.00 & 920.98 & 2769.85 & $100.0 \%$ & $100.0 \%$ & $100.0 \%$ \\
\hline
\end{tabular}

a Values obtained from companies in the study region.

b Allocation factor for slaughtering and rendering using mass-based allocation.

c Allocation factor for slaughtering and rendering using market value-based allocation.

d Allocation factor for slaughtering and rendering using energy-based allocation.

e Valadares Filho et al. (2010).

f Freitas (2007).

g European Commission (2005). 
Table 10

Outputs from transesterification process, its mass, market value and energy content and the respective allocation factors.

\begin{tabular}{|c|c|c|c|c|c|c|}
\hline & $\begin{array}{l}\text { Mass }^{\mathrm{a}} \\
(\mathrm{kg})\end{array}$ & $\begin{array}{l}\text { Market Value }^{\mathrm{a}} \\
\text { (US\$/kg) }\end{array}$ & $\begin{array}{l}\text { Energy } \\
(\mathrm{MJ} / \mathrm{kg})\end{array}$ & $\mathrm{AF}_{\mathrm{t}}[\mathrm{m}]^{\mathrm{b}}$ & $\mathrm{AF}_{\mathrm{t}}[\mathrm{v}]^{\mathrm{C}}$ & $\mathrm{AF}_{\mathrm{t}}[\mathrm{e}]^{\mathrm{d}}$ \\
\hline Biodiesel & 1000.00 & 0.72 & $39.00^{\mathrm{e}}$ & $88.74 \%$ & $98.17 \%$ & $95.03 \%$ \\
\hline Crude glycerin ${ }^{\mathrm{h}}$ & 117.37 & 0.08 & $14.30^{\mathrm{f}}$ & $10.42 \%$ & $1.21 \%$ & $4.09 \%$ \\
\hline Fatty acids & 9.54 & 0.48 & $38.04^{g}$ & $0.85 \%$ & $0.63 \%$ & $0.88 \%$ \\
\hline Totals & 1126.91 & 737.76 & $41,041.27$ & $100.00 \%$ & $100.00 \%$ & $100.00 \%$ \\
\hline
\end{tabular}

${ }^{a}$ Values obtained from companies operating in the studied region.

b Allocation factor for transesterification using mass-based allocation.

c Allocation factor for transesterification process using market value-based allocation.

d Allocation factor for transesterification process using energy-based allocation.

e Rocha et al. (2014).

f Albarelli et al. (2011).

g Oliveira (2014).

h With $80 \%$ glycerol.

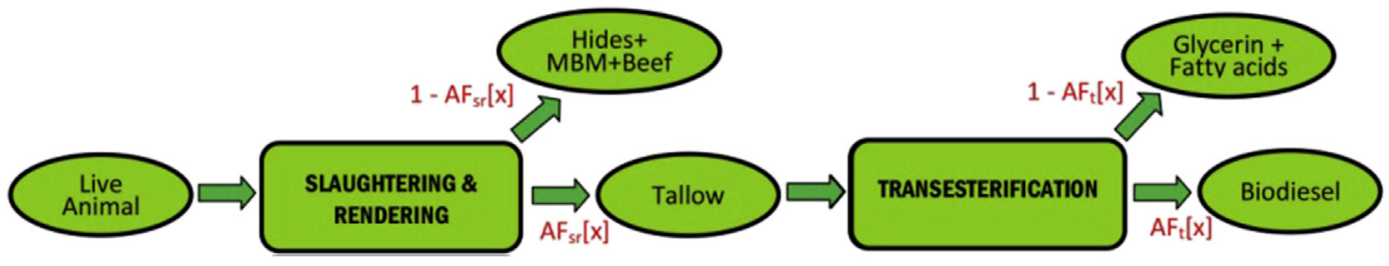

Fig. 8. Tallow biodiesel allocation diagram.

\subsection{Allocation}

Since the S\&R phase has as outputs tallow, meat, hides and MBM, emissions from this phase must be allocated among them. Table 9 shows outputs from S\&R for one animal unit (450 kg), with mass, market value and embodied energy as well as the allocation factors calculated. Gastric-intestinal contents, blood and losses are non-value added waste, sent to treatment companies, so the emissions of these wastes are not considered to calculate the allocation factors. Mass and market values are obtained from companies operating in the studied region. The energy value is calculated using percentage of protein and fat of each animal part (Paulino, 2006; Freitas, 2007; Valadares Filho et al., 2010) and energy content of protein and fat (NASEM, 2016).

From the three allocation factors for tallow in the S\&R phase, the one that uses the market value approach (v) is the smallest, representing less than $2 \%$. It is naturally influenced by a low market value (currently US\$8.58/kg) and the small amount of tallow extracted from each animal $(20.25 \mathrm{~kg})$, while a slaughtered steer costs about US\$697.00. Therefore, using market value to apportion GHG emissions from the $\mathrm{S} \& \mathrm{R}$ process underestimates its environmental impact.

Mass allocation, considering yields of each product obtained from slaughter, also underestimates the environmental impact from tallow, since tallow yield is about 15 times less than other sellable parts of the animal. On the other hand, using energetic allocation with a recommended $28.75 \%$ factor would overestimate emissions, since beef has an energy value seven times lower than tallow. None of the four approaches (non-allocation, mass, market value and energetic allocation) seems adequate to apportion GHG emissions from S\&R, since separately they lead to under or overvaluation of the results. For this reason, a novel approach was adopted, the average of the above-mentioned factors, resulting in $\mathrm{AF}_{\mathrm{Sr} \text { mean }}=12.15 \%$.

The transesterification phase has biodiesel as the main output and glycerin and fatty acids as byproducts. Thus, emissions must be allocated among the main product and byproducts (Fig. 7). Table 10 shows these outputs for $1000 \mathrm{~kg}$ of biodiesel produced. Besides mass for each output, market value and embodied energy are also shown, with their respective allocation factors.

For the transesterification phase, allocating factors remain under $10 \%$ for the different approaches. Glycerin and fatty acids have

Table 11

Allocation factors for slaughtering \& rendering and transesterification phases and accumulated factors of tallow biodiesel life cycle assessment.

\begin{tabular}{|c|c|c|c|c|c|}
\hline & & \multicolumn{3}{|c|}{ Transesterification } & \multirow[b]{2}{*}{$\mathrm{AF}_{\mathrm{t} \text { mean }}{ }^{\mathrm{d}}=93.98 \%$} \\
\hline & & $\mathrm{AF}_{\mathrm{t}}[\mathrm{m}]^{\mathrm{c}}=88.74 \%$ & $\mathrm{AF}_{\mathrm{t}}[\mathrm{v}]^{\mathrm{C}}=98.17 \%$ & $\mathrm{AF}_{\mathrm{t}}[\mathrm{e}]^{\mathrm{C}}=95.03 \%$ & \\
\hline Slaughtering \& Rendering & $\begin{array}{l}\mathrm{AF}_{\mathrm{sr}}[\mathrm{m}]^{\mathrm{a}}=5.97 \% \\
\mathrm{AF}_{\mathrm{sr}}[\mathrm{v}]^{\mathrm{a}}=1.73 \% \\
\mathrm{AF}_{\mathrm{sr}}[\mathrm{e}]^{\mathrm{a}}=28.75 \% \\
\mathrm{AF}_{\mathrm{sr} \text { mean }}{ }^{\mathrm{b}}=12.15 \%\end{array}$ & $\begin{array}{l}\mathrm{AF}_{\mathrm{a}}[\mathrm{m}, \mathrm{m}]^{\mathrm{e}}=5.30 \% \\
\mathrm{AF}_{\mathrm{a}}[\mathrm{v}, \mathrm{m}]^{\mathrm{e}}=1.54 \% \\
\mathrm{AF}_{\mathrm{a}}[\mathrm{e}, \mathrm{m}]^{\mathrm{e}}=25.52 \%\end{array}$ & $\begin{array}{l}\mathrm{AF}_{\mathrm{a}}[\mathrm{m}, \mathrm{v}]^{\mathrm{e}}=5.87 \% \\
\mathrm{AF}_{\mathrm{a}}[\mathrm{v}, \mathrm{v}]^{\mathrm{e}}=1.70 \% \\
\mathrm{AF}_{\mathrm{a}}[\mathrm{e}, \mathrm{v}]^{\mathrm{e}}=28.23 \%\end{array}$ & $\begin{array}{l}\mathrm{AF}_{\mathrm{a}}[\mathrm{m}, \mathrm{e}]^{\mathrm{e}}=5.68 \% \\
\mathrm{AF}_{\mathrm{a}}[\mathrm{v}, \mathrm{e}]^{\mathrm{e}}=1.65 \% \\
\mathrm{AF}_{\mathrm{a}}[\mathrm{e}, \mathrm{e}]^{\mathrm{e}}=27.32 \%\end{array}$ & $\mathrm{AF}_{\mathrm{a} \text { mean }}{ }^{\mathrm{f}}=11.44 \%$ \\
\hline
\end{tabular}

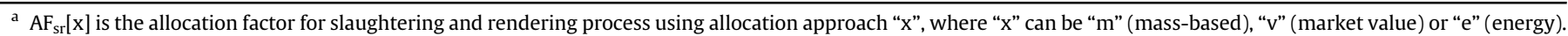

b $\mathrm{AF}_{\mathrm{sr}}$ mean is the mean allocation factor for slaughtering and rendering.

c $\mathrm{AF}_{\mathrm{t}}[\mathrm{y}]$ is the allocation factor for transesterification using allocation approach "y", where "y" can be "m" (mass-based), "v" (market value) or "e" (energy).

${ }^{d} \mathrm{AF}_{\mathrm{t}}$ mean is the mean allocation factor for transesterification.

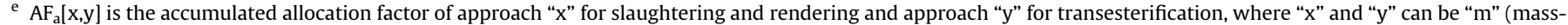
based), "v" (market value) or "e" (energy).

${ }^{\mathrm{f}} \mathrm{AF}_{\mathrm{a} \text { mean }}$ is mean accumulated allocation factor. 
Table 12

Increment in annual GHG emissions per hectare due to each phase of tallow biodiesel production in the Dourados micro-region, Mato Grosso do Sul state, Brazil.

\begin{tabular}{|c|c|c|c|c|c|c|c|c|c|}
\hline \multirow[b]{2}{*}{ Land Use Change } & \multirow{2}{*}{$\begin{array}{l}\text { Without allocation } \\
\left(\mathrm{kg} \mathrm{CO}_{2} \mathrm{eq} \mathrm{ha} \mathrm{ha}^{-1} \mathrm{y}^{-1}\right)\end{array}$} & \multicolumn{2}{|c|}{$\begin{array}{l}\text { Using mass allocation } \\
\left(\mathrm{kg} \mathrm{CO}_{2} \mathrm{eq} \mathrm{ha} \mathrm{ha}^{-1} \mathrm{y}^{-1}\right)\end{array}$} & \multicolumn{2}{|c|}{$\begin{array}{l}\text { Using market value } \\
\text { allocation } \\
\left(\mathrm{kg} \mathrm{CO}_{2} \mathrm{eq} \mathrm{ha} \mathrm{ha}^{-1} \mathrm{y}^{-1}\right)\end{array}$} & \multicolumn{2}{|c|}{$\begin{array}{l}\text { Using energy allocation } \\
\left(\mathrm{kg} \mathrm{CO}_{2} \mathrm{eq} \mathrm{ha}\right. \\
\left.\mathrm{ha}^{-1} \mathrm{y}^{-1}\right)\end{array}$} & \multicolumn{2}{|c|}{$\begin{array}{l}\text { Using mean allocation } \\
\text { (mass, value and energy) } \\
\left(\mathrm{kg} \mathrm{CO}_{2} \text { eq ha }{ }^{-1} \mathrm{y}^{-1}\right)\end{array}$} \\
\hline & & $\mathrm{AF}_{\mathrm{a}}[\mathrm{m}, \mathrm{m}]^{\mathrm{a}}=5.3 \%$ & 19.387 & $\mathrm{AF}_{\mathrm{a}}[\mathrm{v}, \mathrm{v}]^{\mathrm{a}}=1.7 \%$ & 6.218 & $\mathrm{AF}_{\mathrm{a}}[\mathrm{e}, \mathrm{e}]^{\mathrm{a}}=27.3 \%$ & 99.909 & $\mathrm{AF}_{\mathrm{a} \text { mean }}{ }^{\mathrm{C}}=11.4 \%$ & 41.838 \\
\hline Cattle Farming & 11.487 & $\mathrm{AF}_{\mathrm{a}}[\mathrm{m}, \mathrm{m}]^{\mathrm{a}}=5.3 \%$ & 0.609 & $\mathrm{AF}_{\mathrm{a}}[\mathrm{v}, \mathrm{v}]^{\mathrm{a}}=1.7 \%$ & 0.195 & $\mathrm{AF}_{\mathrm{a}}[\mathrm{e}, \mathrm{e}]^{\mathrm{a}}=27.3 \%$ & 3.139 & $\mathrm{AF}_{\mathrm{a} \text { mean }}{ }^{\mathrm{C}}=11.4 \%$ & 1.314 \\
\hline Cattle Transport & 0.133 & $\mathrm{AF}_{\mathrm{a}}[\mathrm{m}, \mathrm{m}]^{\mathrm{a}}=5.3 \%$ & 0.007 & $\mathrm{AF}_{\mathrm{a}}[\mathrm{v}, \mathrm{v}]^{\mathrm{a}}=1.7 \%$ & 0.002 & $\mathrm{AF}_{\mathrm{a}}[\mathrm{e}, \mathrm{e}]^{\mathrm{a}}=27.3 \%$ & 0.036 & $\mathrm{AF}_{\mathrm{a} \text { mean }}{ }^{\mathrm{C}}=11.4 \%$ & 0.015 \\
\hline Slaughtering\&Rendering & 0.069 & $\mathrm{AF}_{\mathrm{a}}[\mathrm{m}, \mathrm{m}]^{\mathrm{a}}=5.3 \%$ & 0.004 & $\mathrm{AF}_{\mathrm{a}}[\mathrm{v}, \mathrm{v}]^{\mathrm{a}}=1.7 \%$ & 0.001 & $\mathrm{AF}_{\mathrm{a}}[\mathrm{e}, \mathrm{e}]^{\mathrm{a}}=27.3 \%$ & 0.019 & $\mathrm{AF}_{\mathrm{a} \text { mean }}{ }^{\mathrm{C}}=11.4 \%$ & 0.008 \\
\hline Tallow Transport & 0.007 & $\mathrm{AF}_{\mathrm{t}}[\mathrm{m}]^{\mathrm{b}}=88.7 \%$ & 0.006 & $\mathrm{AF}_{\mathrm{t}}[\mathrm{v}]^{\mathrm{b}}=98.2 \%$ & 0.007 & $\mathrm{AF}_{\mathrm{t}}[\mathrm{e}]^{\mathrm{b}}=95.0 \%$ & 0.007 & $\mathrm{AF}_{\mathrm{t} \text { mean }}{ }^{\mathrm{d}}=94.0 \%$ & 0.007 \\
\hline Transesterification & 0.021 & $\mathrm{AF}_{\mathrm{t}}[\mathrm{m}]^{\mathrm{b}}=88.7 \%$ & 0.019 & $\mathrm{AF}_{\mathrm{t}}[\mathrm{v}]^{\mathrm{b}}=98.2 \%$ & 0.021 & $\mathrm{AF}_{\mathrm{t}}[\mathrm{e}]^{\mathrm{b}}=95.0 \%$ & 0.020 & $\mathrm{AF}_{\mathrm{t} \text { mean }}{ }^{\mathrm{d}}=94.0 \%$ & 0.020 \\
\hline$\Delta \mathrm{E}^{\mathrm{e}}$ & 377.372 & & 20.032 & & 6.445 & & 103.129 & & 43.202 \\
\hline
\end{tabular}

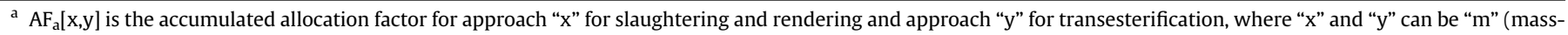
based), "v" (market value) or "e" (energy).

${ }^{\mathrm{b}} \mathrm{AF}_{\mathrm{t}}[\mathrm{y}]$ is the allocation factor for transesterification using allocation approach "y", where " $\mathrm{y}$ " can be "m" (mass-based), "v" (market value) or "e" (energy).

c $\mathrm{AF}_{\mathrm{a}}$ mean is the mean accumulated allocation factor.

d $\mathrm{AF}_{\mathrm{t} \text { mean }}$ is the mean allocation factor for transesterification.

e $\Delta \mathrm{E}$ is total increment in annual GHG emissions per hectare due to tallow biodiesel production for each allocation approach.

low proportions in terms of mass, being $10.42 \%$ and $0.85 \%$. After excluding fatty acids due to their very low mass, the ratio between energy content of biodiesel and glycerin is around 3:1. The allocation factor using energy is $7 \%$ higher than the mass allocation factor. Regarding market value, the ratio is even higher (about 10:1) and the allocation factor based on market value is $10 \%$ higher than that based on mass. As shown for S\&R, a fifth approach - the average of all transesterification allocation factors - was used $\left(\mathrm{AF}_{\mathrm{t}}\right.$ mean $=93.98 \%$ ).

Since the production chain is a series of industrial processes (Fig. 8), it is necessary to calculate the accumulated allocation factors, which must be applied to emissions until obtaining tallow. Tallow transport and transesterification phases have their emissions allocated using the allocation factor of the transesterification phase.

Since there are three possible types of allocation for each of the phases, there are nine accumulated allocation factors, as show in Table 11. For the phases prior to tallow transport, this work uses just the accumulated factors from the main diagonal and their average $\left(\mathrm{AF}_{\mathrm{a}}[\mathrm{m}, \mathrm{m}], \mathrm{AF}_{\mathrm{a}}[\mathrm{v}, \mathrm{v}], \mathrm{AF}_{\mathrm{a}}[\mathrm{e}, \mathrm{e}]\right.$ and $\mathrm{AF}_{\mathrm{a}}$ mean $)$. For tallow transport and transesterification phases, transesterification allocation factors and their average are used $\left(\mathrm{AF}_{\mathrm{t}}[\mathrm{m}], \mathrm{AF}_{\mathrm{t}}[\mathrm{v}], \mathrm{AF}_{\mathrm{t}}[\mathrm{e}]\right.$ and $\mathrm{AF}_{\mathrm{t}}$ mean $)$.

\subsection{Final results}

Finally, Table 12 shows the increments in annual GHG emissions per hectare caused by tallow biodiesel for each major phase of its life cycle under different allocation approaches: non-allocation, mass, market value and energetic allocation and average of the three allocation methods. It is worth noting that even without allocation, the processing and transport phases have relatively small participation in total GHG emissions increment per hectare (between $0.002 \%$ and $0.035 \%$ ).

Since tallow is a byproduct of beef, the non-allocation approach is not suitable, because it directs all impact from the production chain to tallow biodiesel. Other than this approach, the largest increment in GHG emissions per area happens when the selection is energy content, since in the $S \& R$ and transesterification processes, where there is allocation, the major products (tallow and biodiesel) have the highest energy values. The single approach resulting in the smallest emissions is market value, since the allocation factor is the product of two values (mass and tallow market value), which are comparatively much lower than the values from the other process's outputs.

The allocation types adopted did not significantly influence the impact share of each step in the overall biodiesel production. As a whole, LUC is responsible for more than $96 \%$ of GHG emissions related to the tallow biodiesel production chain, while cattle farming is responsible for 3\%. Emissions from the other phases are of very little relevance. It is interesting to notice that the literature reviewed did not include the influence of LUC on emissions from tallow biodiesel, which represented almost all the GHG emissions evaluated in this work.

Soybean is the major agricultural product from the studied area and its oil for biodiesel production is a main product rather than a byproduct. When comparing regional GHG emissions from soybean biodiesel for the same period, using the same approach, soybean biodiesel showed an increment in annual GHG emissions of $50.16 \mathrm{~kg} \mathrm{CO}_{2}$ eq ha ${ }^{-1} \mathrm{y}^{-1}$ (Esteves et al., 2016). The figures obtained, i.e. $43.202 \mathrm{~kg} \mathrm{CO}_{2} \mathrm{eq} \mathrm{ha} \mathrm{ha}^{-1} \mathrm{y}^{-1}$, using mean allocation factors, show that tallow biodiesel emissions per area are $17 \%$ lower. However, despite similar energy content, tallow is a low volume byproduct, ( $4.29 \mathrm{~kg}$ of tallow ha ${ }^{-1}$ ) i.e., 110 times lower than soybean oil yield ( $471.38 \mathrm{~kg}$ of soybean oil ha ${ }^{-1}$ ) (Table A2, Supplementary Material). Tallow can also be considered as a residue because of its low market value. Converting tallow into biodiesel reduces environmental impacts of beef production regarding GHG emissions.

Sensitivity analysis was performed, consisting of variations of $10 \%$ in the main impacting parameters, namely savannah, forest and crop into pasture. The results showed variations of $7.8 \%, 1.9 \%$ and $0.2 \%$, in emissions from tallow biodiesel production. Consequently, changes from crop to pasture are an environmentally preferable option. Nevertheless, this substitution may not be feasible for economic and social reasons, since soybean is the main product of the region. In this work, from $15.8 \%$ of LUC, $88.5 \%$ was changes from natural areas to pasture. Land use management is thus essential to preserve the remaining natural areas, making the process more sustainable.

\section{Conclusions}

This study introduced a novel method to assess regional GHG emissions per area of tallow biodiesel, including, besides the industrial phase, LUC, transport and farming phases. The allocation adopted to distribute impacts among chain products is a new approach that uses mean of mass, market value and energy allocations.

To support decision making on biodiesel production policies, this work assumes an approach of directing all tallow produced in the DMR to biodiesel, increasing its regional impact. Considering that tallow is a byproduct of the beef supply chain with limited high-end options for use, it can be classified as waste, so its 
allocation to produce biodiesel reduces the environmental impact of the beef production chain. Producing biodiesel from this low value byproduct has environmental benefits at the regional scale. Increasing the use of tallow for biodiesel would reduce the use of soybean oil for energy, a social benefit due to the relevance of soybean as human food.

The method proposed in this work can be improved by applying it: (i) to different regions of Brazil and the world, (ii) with the integration of different feedstocks in the transesterification phase, and (iii) with other impact categories, such as water footprint and energy content, exploring the water-energy nexus.

Ultimately, LUC represents almost all tallow biodiesel GHG emissions, which demonstrates the importance of including LUC assessment in the life cycle of this product. Beside this, land use optimization between crops and livestock grazing is essential to preserve remaining natural areas and improve tallow biodiesel sustainability.

\section{Acknowledgements}

Grant from CNPq no. 404778/2013-5 is gratefully acknowledged. Elisa M.M. Esteves acknowledges scholarship from ANP and CAPES. Ofelia Q.F. Araujo acknowledges scholarship (research productivity) from CNPq.

\section{Appendix A. Supplementary data}

Supplementary data related to this article can be found at http:// dx.doi.org/10.1016/j.jclepro.2017.03.063.

\section{Nomenclature}

Abbreviations and chemical formulas

ABGB Above and below ground biomass

ABP Animal byproduct

C Carbon

CDM Clean Development Mechanism

$\mathrm{CH}_{4} \quad$ Methane

$\mathrm{CO}_{2} \quad$ Carbon dioxide

$\mathrm{CO}_{2}$ eq Carbon dioxide equivalent

CS Carbon stock

DMR Dourados micro-region (a micro-region in Mato Grosso do Sul state, Brazil)

DOM Dead organic matter

GHG Greenhouse gases

GIS Geographic information system

GWP $_{100}$ Global warming potential for 100 years

IPCC Intergovernmental Panel on Climate Change

LCA Life cycle assessment

LUC Land use change

LULUCF Land use and land use change and forestry

MBM Meat and bone meal

MS Mato Grosso do Sul state (a Brazilian state)

$\mathrm{N} \quad$ Nitrogen

$\mathrm{N}_{2} \mathrm{O} \quad$ Nitrous oxide

PNPB National program for biodiesel production and use in Brazil

S\&R Slaughtering \& Rendering

SOC Soil Organic Carbon

TNCB Third National Communication of Brazil to UNFCCC

UNFCCC United Nations Framework Convention on Climate Change
Symbols

$i \quad$ Previous land use, which can be crop (Cp), forest (F) or savannah (Sv)

j Different types of land use, which can be pasture (Pt), crop (Cp), forest (F) or savannah (Sv)

$n \quad$ Natural areas, which can be forest (F) or savannah (Sv)

a Anthropized areas, which can be crop (Cp) or pasture (Pt)

Cp Crop

Pt Pasture

F $\quad$ Forest

Sv Savannah

$\mathrm{AF}_{\mathrm{Sr}}[\mathrm{x}]$ Allocation factor of slaughtering and rendering process using " $\mathrm{x}$ " allocation approach, where " $\mathrm{x}$ " can be " $\mathrm{m}$ " (mass-based), "v" (market value) or "e" (energy)

$\mathrm{AF}_{\mathrm{t}}[\mathrm{y}] \quad$ Allocation factor of transesterification process using " $\mathrm{y}$ " allocation approach, where " $y$ " can be " $\mathrm{m}$ " (mass-based), "v" (market value) or "e" (energy)

$\mathrm{AF}_{\mathrm{a}}[\mathrm{x}, \mathrm{y}]$ Accumulated allocation factor of " $\mathrm{x}$ " approach for slaughtering and rendering process and " $y$ " approach for transesterification process, where " $x$ " and " $y$ " can be " $m$ " (mass-based), "v" (market value) or "e" (energy)

$\mathrm{AF}_{\mathrm{t}}$ mean Mean allocation factor of transesterification process

$\mathrm{AF}_{\mathrm{Sr}}$ mean Mean allocation factor of slaughtering and rendering process

$\mathrm{AF}_{\mathrm{a}}$ mean Mean accumulated allocation factor

$\Delta E \quad$ Increment in annual GHG emissions of biodiesel production per area, $\mathrm{kg} \mathrm{CO}_{2} \mathrm{eq} \mathrm{ha}{ }^{-1} \mathrm{y}^{-1}$

$A \%$ Share of natural areas in the studied area, dimensionless

$A_{T} \quad$ Total area under analysis, ha

$A_{i-P t} \quad$ Area that changes from land use " $i$ " to pasture (Pt), ha

$B D_{e} \quad$ Annual emissions due to biodiesel production, $\mathrm{kg} \mathrm{CO} \mathrm{CO}_{2} \mathrm{eq}$ ha ${ }^{-1} \mathrm{y}^{-1}$

$\mathrm{CF}_{e} \quad$ Annual emission per head due to enteric fermentation, manure management in cattle farming, $\mathrm{kg} \mathrm{CO}_{2}$ eq ha ${ }^{-1} \mathrm{y}^{-1}$

$C S_{A B G B}$ Carbon stock in above and below ground biomass, $\mathrm{kg} \mathrm{Cha} \mathrm{ha}^{-1}$

$C S_{\text {DOM }}$ Carbon stock in dead organic matter, $\mathrm{kg} \mathrm{C} \mathrm{ha}^{-1}$

$\mathrm{CS}_{\mathrm{SOC}} \quad$ Carbon stock in soil organic carbon, $\mathrm{kg} \mathrm{C} \mathrm{ha-1}$

CS Carbon stock, $\mathrm{kg} \mathrm{C} \mathrm{ha}^{-1}$

$D e_{P R P} \quad$ Direct $\mathrm{N}_{2} \mathrm{O}$ emission due to urine and dung from grazing animals, $\mathrm{kg} \mathrm{CO}_{2}$ eq ha ${ }^{-1} \mathrm{y}^{-1}$

$D e_{S O M}$ Direct $\mathrm{N}_{2} \mathrm{O}$ emission due to mineralization of nitrogen, in association with loss of soil carbon from soil organic matter, $\mathrm{kg} \mathrm{CO}$ eq ha ${ }^{-1} \mathrm{y}^{-1}$

$E F_{1} \quad$ Emission factor for $\mathrm{N}_{2} \mathrm{O}$ from nitrogen inputs, $\mathrm{kg} \mathrm{N}_{2} \mathrm{O}-\mathrm{N}$ $(\mathrm{kg} \mathrm{N})^{-1}$

$E F_{3 P R P} \quad$ Emission factor for $\mathrm{N}_{2} \mathrm{O}$ emissions from urine and dung $\mathrm{N}$ deposited in pasture, range and paddock by grazing animals, $\mathrm{kg} \mathrm{N}_{2} \mathrm{O}-\mathrm{N}$ ( $\mathrm{kg} \mathrm{N}$ input) $)^{-1}$

$\mathrm{EF}_{4} \quad$ Emission factor for $\mathrm{N}_{2} \mathrm{O}$ emissions from atmospheric deposition of $\mathrm{N}$ on soil and water surfaces, $\mathrm{kg} \mathrm{N} \mathrm{N}_{2} \mathrm{O}-\mathrm{N}(\mathrm{kg}$ of $\mathrm{N}$ additions) ${ }^{-1}$

$E_{5} \quad$ Emission factor for $\mathrm{N}_{2} \mathrm{O}$ emissions from nitrogen leaching and runoff, $\mathrm{kg} \mathrm{N} \mathrm{N}_{2} \mathrm{O}-\mathrm{N}$ ( $\mathrm{kg}$ of $\mathrm{N}$ leached and runoff) $)^{-1}$

$E F_{a} \quad$ Annual emission factor of adults due to enteric fermentation and manure management, $\mathrm{kg} \mathrm{CO} 2 \mathrm{eq}$ (head) ${ }^{-1} \mathrm{y}^{-1}$

$E F_{b c} \quad$ Annual emission factor of breeding cows due to enteric fermentation and manure management, $\mathrm{kg} \mathrm{CO} \mathrm{CO}_{2} \mathrm{eq}$ (head) ${ }^{-1} \mathrm{y}^{-1}$

$E F_{r} \quad$ Annual emission factor of rearing due to enteric fermentation and manure management, $\mathrm{kg} \mathrm{CO} 2 \mathrm{eq}$ (head) ${ }^{-1} \mathrm{y}^{-1}$ 
$F_{I_{a}} \quad$ Input factor, reflecting the difference in soil organic carbon associated with different levels of carbon input to soil compared to the standard soil organic carbon, for anthropized areas, dimensionless

$F_{L U_{a}} \quad$ Land use factor, reflecting the difference in soil organic carbon associated with the type of land use when compared to the standard soil organic carbon, for anthropized areas, dimensionless

$F_{M G_{a}} \quad$ Management factor, reflecting the difference in soil organic carbon associated with the main land management practice compared to the standard soil organic carbon, for anthropized areas, dimensionless

Frac $_{\text {GASM }}$ Fraction of urine and dung $\mathrm{N}$ deposited on pasture by grazing animals, dimensionless

Frac $_{\text {LEACH-(H) }}$ Fraction of all $\mathrm{N}$ added to or mineralized in managed soils through leaching and runoff, dimensionless

$I_{P R P}$ Indirect $\mathrm{N}_{2} \mathrm{O}$ emission due to urine and dung of animals during grazing, $\mathrm{kg} \mathrm{CO}$ eq ha ${ }^{-1} \mathrm{y}^{-1}$

$\mathrm{Ie}_{\mathrm{SOM}}$ Indirect $\mathrm{N}_{2} \mathrm{O}$ emission due to mineralization of nitrogen, in association with loss of soil carbon, $\mathrm{kg} \mathrm{CO}_{2} \mathrm{eq} \mathrm{ha} \mathrm{ha}^{-1} \mathrm{y}^{-1}$

$L U C_{e_{\mathrm{CO}_{2}}}$ Annual carbon dioxide emissions due to land use change, $\mathrm{kg} \mathrm{CO}$ eq ha ${ }^{-1} \mathrm{y}^{-1}$

$L U C_{e_{N_{2} \mathrm{O} \text { dir }}}$ Annual direct nitrous oxide emissions due to land use change, $\mathrm{kg} \mathrm{CO}$ eq ha ${ }^{-1} \mathrm{y}^{-1}$

$L U C_{e_{N_{2} \mathrm{O} \text { indir }}}$ Annual indirect nitrous oxide emissions due to land use change, $\mathrm{kg} \mathrm{CO}_{2} \mathrm{eq} \mathrm{ha} \mathrm{h}^{-1} \mathrm{y}^{-1}$

$L U C_{e_{N_{2} O} \mathrm{O}}$ Annual nitrous oxide emissions due to land use change, $\mathrm{kg} \mathrm{CO}_{2} \mathrm{eq} \mathrm{ha} \mathrm{ha}^{-1} \mathrm{y}^{-1}$

$L U C_{e(i-P t)}$ Annual emissions due to land use change from previous land use " $i$ " to pasture (Pt), $\mathrm{kg} \mathrm{CO}_{2} \mathrm{eq} \mathrm{ha}{ }^{-1} \mathrm{y}^{-1}$

$\mathrm{LUC}_{e} \quad$ Annual emissions due to land use change, $\mathrm{kg} \mathrm{CO}_{2} \mathrm{eq}$ $\mathrm{ha}^{-1} \mathrm{y}^{-1}$

$M S_{P R P} \quad$ Fraction of total annual N excretion for each cattle stock in pasture, range and paddock, dimensionless

$N_{C H} \quad$ Average of the annual stocking rates during the study period, in the area subject to LUC into pasture, animal $\mathrm{ha}^{-1}$

$N_{\text {rate }} \quad$ Default $\mathrm{N}$ excretion rate, $\mathrm{kg} \mathrm{N}(\mathrm{kg} \text { animal })^{-1} \mathrm{y}^{-1}$

$N_{y} \quad$ Number of years in the study period, $\mathrm{y}$

$R \quad$ Ratio of the mass of carbon to the mass of nitrogen in soil organic matter, $\operatorname{kg~C}(\operatorname{kg~N})^{-1}$

$\mathrm{SR}_{e} \quad$ Annual emission from slaughtering and rendering phase, $\mathrm{kg} \mathrm{CO}_{2}$ eq ha ${ }^{-1} \mathrm{y}^{-1}$

$\mathrm{Sr}_{a} \quad$ Stocking rate of adults, head ha $\mathrm{ha}^{-1}$

$\mathrm{Sr}_{b} \quad$ Stocking rate of bulls, head ha-1

$\mathrm{Sr}_{b c} \quad$ Stocking rate of breeding cows, head ha $\mathrm{h}^{-1}$

$\mathrm{Sr}_{r} \quad$ Stocking rate of rearing, head ha ${ }^{-1}$

$\mathrm{TPC}_{e} \quad$ Annual emission from cattle transportation, $\mathrm{kg} \mathrm{CO} \mathrm{CO}_{2} \mathrm{eq}$ $\mathrm{ha}^{-1} \mathrm{y}^{-1}$

$\mathrm{TPt}_{e} \quad$ Annual emission from tallow transportation, $\mathrm{kg} \mathrm{CO} \mathrm{CO}_{2} \mathrm{eq}$ $\mathrm{ha}^{-1} \mathrm{y}^{-1}$

$\operatorname{Tr}_{e} \quad$ Annual emission from transesterification phase, $\mathrm{kg} \mathrm{CO} \mathrm{CO}_{2} \mathrm{eq}$ $\mathrm{ha}^{-1} \mathrm{y}^{-1}$

$t_{a} \quad$ Time of adult grazing, months

$t_{b} \quad$ Time of bull grazing, months

$t_{p} \quad$ Pregnancy time, months

$t_{r} \quad$ Time of rearing grazing, months

$t_{s} \quad$ Suckling time, months

TAM Typical animal mass, $\mathrm{kg}$ animal (animal) ${ }^{-1}$

$\mathrm{Y}_{\mathrm{g}} \quad$ Average time in which the area was used as pasture, $\mathrm{y}$

\section{References}

Albarelli, J.Q., Santos, D.T., Holanda, M.R., 2011. Energetic and economic evaluation of waste glycerol cogeneration. Braz. J. Chem. Eng. 28 (4), 691-698. http:// dx.doi.org/10.1590/S0104-66322011000400014.

Almeida, R.G., Andrade, C.M.S., Paciullo, D.S.C., 2013. Brazilian agroforestry systems for cattle and sheep. Trop. Grassl.Forrajes Trop. 1, 175-183. Available at: www tropicalgrasslands.info/index.php/tgft/article/view/83 (Accessed in 10 Sepember 2016).

ANP, 2016a. Brazilian National Petroleum, Natural Gas and Biofuels Agency (Agência Nacional de Petróleo, Gas Natural e Biocombustíveis). Biodiesel monthly report (in Portuguese). Available at: www.anp.gov.br/wwwanp/publicacoes/boletinsanp/2386-boletim-mensal-do-biodiesel (Accessed: 22 Sepember 2016).

ANP, 2016b. Brazilian National Petroleum, Natural Gas and Biofuels Agency (Agência Nacional de Petróleo, Gas Natural e Biocombustíveis). Biodiesel Production (in Portuguese). Available at: www.anp.gov.br/wwwanp/dados-estatisticos (accessed: 22 Sepember 2016).

Bergmann, J.C., Tupinamba, D.D., Acosta, O.Y.A., 2013. Biodiesel Production in Brazil and alternative biomass feedstocks. Renew. Sustain. Energy Rev. 21, 411-420. http://dx.doi.org/10.1016/j.rser.2012.12.058.

Bernoux, M., Carvalho, M.C.S., Volkoff, B., Cerri, C.C., 2002. Brazil's soil carbon stocks. Soil Sci. Soc. Am. J. 66, 888-896. http://dx.doi.org/10.2136/sssaj2002.8880.

Brander, M., Hutchison, C., Sherrington, C., Ballinger, A., Beswick, C., Baddeley, A. Black, M., Woods, J., Murphy, R., 2009. Methodology and evidence base on the indirect greenhouse gas effects of using wastes, residues, and by-products for biofuels and bioenergy. Report to the Renewable Fuels Agency and the Department for Energy and Climate Change. Report PR-091007-A, 30 November 2009. Available at: www.bioenergywiki.net/images/a/a5/Ecometrica Methodology.pdf (Accessed: 22 Sepember 2016).

Castanheira, E.G., Grisoli, R., Freire, F., 2014. Environmental sustainability of biodiesel in Brazil. Energy Policy 65, 680-691. http://dx.doi.org/10.1016/ j.enpol.2013.09.062.

CONAB, 2016. Brazilian National Supply Company. Acompanhamento da Safra brasileira grãos (in Portuguese). Available at: www.conab.gov.br/OlalaCMS/ uploads/arquivos/16_09_09_15_18_32_boletim_12_setembro.pdf (Accessed: 08 October 2016).

Cunha, M.E., Krause, L.C., Moraes, M.S.A., 2009. Beef tallow biodiesel produced in a pilot scale. Fuel Process Technol. 90, 570-575. http://dx.doi.org/10.1016/ j.fuproc.2009.01.001.

Dick, M., da Silva, M.A., Dewes, H., 2015. Mitigation of environmental impacts of beef cattle production in southern Brazil - evaluation using farm-based life cycle assessment. J. Clean. Prod. 87, 58-67. http://dx.doi.org/10.1016/ j.jclepro.2014.10.087.

Dufour, J., Iribarren, D., 2012. Life cycle assessment of biodiesel production from free fatty acid-rich wastes. Renew. energy 38 (1), 155-162. http://dx.doi.org/ 10.1016/j.renene.2011.07.016.

EMBRAPA, 2016. Available at: http://cloud.cnpgc.embrapa.br/sac/2012/09/14/comofaco-para-calcular-quantos-ua\%C2\%B4sha-ou-lotacao-animal/ (Accessed: 24 July 2016).

Encinar, J.M., Sánchez, N., Martínez, G., García, L., 2011. Study of biodiesel production from animal fats with high free fatty acid content. Bioresour. Technol. 102, 10907-10914. http://dx.doi.org/10.1016/j.biortech.2011.09.068.

Esteves, V.P.P., Esteves, E.M.M., Bungenstab, D.J., Loebmann, D.G.S.W., Victoria, D.C., Vicente, L.E., Araujo, O.Q.F., Morgado, C.R.V., 2016. Land use change (LUC) analysis and life cycle assessment (LCA) of Brazilian soybean biodiesel. Clean Technol. Environ. Policy 18, 1655-1673. http://dx.doi.org/10.1007/s10098-0161161-8.

European Commission, 2005. Integrated Pollution Prevention and Control Reference Document on Best Available Techniques in the Slaughterhouses and Animal By-products Industries. Seville, Spain. Available at: http://eippcb.jrc.ec. europa.eu/reference/BREF/sa_bref_0505.pdf (Accessed in 20 September 2016).

Figueiredo, E.B., Jayasundara, S., Bordonal, R.O., Berchielli, T.T., Reis, R.A., WagnerRiddle, C., La Scala Jr., N., 2017. Greenhouse gas balance and carbon footprint of beef cattle in three contrasting pasture-management systems in Brazil. J. Clean. Prod. 142, 420-431. http://dx.doi.org/10.1016/j.jclepro.2016.03.132.

Firestone, D., 2006. Physical and Chemical Characteristics of Oils, Fats, and Waxes, second ed. Am. Oil Chemists' Soc. Press, Champaign, IL, USA. ISBN-13: 978-1893997-99-8.

Freitas, E.A., 2007. Estudo comparativo das características do couro e efluente bruto de processo de curtimento convencional versus processo com reciclagem direta de banho de curtimento. Dissertation (Master in Environmental Technology). Federal University of Mato Grosso do Sul, Campo Grande, MS, Brazil (in Portuguese). Available at: https://sistemas.ufms.br/sigpos/portal/trabalhos/ download/54/cursold:33 (Accessed: 03 November 2016).

Horne, R.E., Matthews, R., 2004. BIOMITRE Technical Manual. Farnham, Surrey, UK Available at: www.globalbioenergy.org/uploads/media/0411_BIOMITRE_ Technical_Manual.pdf (Accessed: 03 November 2016).

IAGRO, 2016. Official Animal and Plant Health Protection Agency of Mato Grosso Do Sul State (In Portuguese). Available at: www2.iagro.ms.gov.br/ (Accessed: 08 May 2016).

IBGE, 2016a. Brazilian Institute of Geography and Statistic. Aggregated Data Bank (In Portuguese). Available at: www.sidra.ibge.gov.br/bda/pesquisas/pas/default.asp (Accessed: 22 September 2016).

IBGE, 2016b. Brazilian Institute of Geography and Statistic. Historical Series and Statistics (In Portuguese). Available at: http://seriesestatisticas.ibge.gov.br (Accessed: 20 June 2016).

IPCC, 2003. Intergovernmental Panel on climate change. In: Good Practice Guidance for Land Use, Land-use Change and Forestry. Hayama, Kanagawa, Japan. 
Available at: www.ipcc-nggip.iges.or.jp/public/gpglulucf/gpglulucf_contents. html (Accessed: 22 June 2016).

IPCC, 2006. Intergovernmental Panel on climate change. In: Agriculture, Forestry and Other Land Use. 2006 IPCC Guidelines for National Greenhouse Gas Inventories, Vol. 4. Hayama, Kanagawa, Japan. Available at: www.ipcc-nggip.iges. or.jp/public/2006gl/vol4.html (Accessed: 22 June 2016).

IPCC, 2007. Intergovernmental Panel on climate change. In: Climate Change 2007. The Physical Science Basis. Contribution of Working Group I to the Fourth Assessment Report of IPCC. New York, NY, USA. Available at: www.ipcc.ch/pdf/ assessment-report/ar4/wg1/ar4_wg1_full_report.pdf (Accessed: 22 June 2016).

ISO, 2006a. International Standardization Organization. Environmental Management - Life Cycle Assessment - Principles and Framework, ISO 14040. Geneva, Switzerland. Available at: www.iso.org/standard/37456.html (Accessed: 22 June 2016).

ISO, 2006b. International Standardization Organization. Environmental Management - Life Cycle Assessment - Requirements and Guidelines, ISO 14044. Geneva, Switzerland. Available at: www.iso.org/standard/38498.htm (Accessed: 22 June 2016).

MSTI, 2015a. Ministry of Science, Technology and Innovation. Reference Report of Methane Emissions from Enteric Fermentation and Manure Management of Agriculture Sector of Third National Communication of Brazil to the United Nations Framework Convention on Climate Change (In Portuguese), Brasilia, DF, Brazil. Available at: http://sirene.mcti.gov.br/documents/1686653/1705489/RR AGRICULTURA_III+Invent\%C3\%A1rio.zip/aaccfd9f-c798-4ca2-8015a2271de3325a (Accessed: 03 November 2016).

MSTI, 2015b. Ministry of Science, Technology and Innovation. Reference Report of Land Use and Land Use Change and Forestry Sector of Third Nationa Communication of Brazil to the United Nations Framework Convention on Climate Change (In Portuguese), Brasilia, DF, Brazil. Available at: http://sirene. mcti.gov.br/documents/1686653/1706165/RR_LULUCF_Mudan\%C3\%

A7a+de+Uso+e+Floresta.pdf/11dc4491-65c1-4895-a8b6-e96705f2717a (Accessed: 03 November 2016).

MSTI, 2016. Ministry of Science, Technology and Innovation. Third National Communication of Brazil to the United Nations Framework Convention on Climate Change. Secretariat of Policies and Programs of Research and Development General Coordination of Global Climate Change, Brasilia, DF, Brazil. Available at: http://sirene.mcti.gov.br/documents/1686653/1706740/MCTI SUMARIO+EXECUTIVO_ingles.pdf/3404490b-700d-4fe0-b877-6c3511994e69 (Accessed: 03 November 2016).

NASEM, 2016. National Academies of Sciences, Engineering, and Medicine. Nutrient Requirements of Beef Cattle, Eighth Revised Edition. USA. Press, Washington, DC. http://dx.doi.org/10.17226/19014.

Nelson, R.G., Schrock, M.D., 2006. Energetic and economic feasibility associated with the production, processing, and conversion of beef tallow to a substitute diesel fuel. Biomass Bioenerg. 30, 584-591. http://dx.doi.org/10.1016 j.biombioe.2005.09.005.

Niederl-Schmidinger, A., Narodoslawsky, M., 2008. Life cycle assessment as an engineer's tool? J. Clean. Prod. 16, 245-252. http://dx.doi.org/10.1016 j.jclepro.2006.08.024.

Nogueira, L.A.H., 2011. Does biodiesel make sense? Energy 36 (6), 3659-3666 http://dx.doi.org/10.1016/j.energy.2010.08.035.

OECD/FAO, 2015. Organization for Economic Co-operation and Development/Food and Agriculture Organization of the United Nations. Agricultural Outlook, 20152024. OECD Publishing, Paris, France. http://dx.doi.org/10.1787/agr_outlook- 2015-en.

Oliveira, L.E., 2014. Avaliação dos parâmetros térmicos e calorimétricos das matérias-primas lipídicas e dos respectivos biodieseis produzidos. Thesis (Doctor in Industrial Biotechnology). São Paulo University, Lorena, SP, Brazil (in Portuguese). Available at: www.teses.usp.br/teses/disponiveis/97/97131/tde24032015-170014/pt-br.php (accessed: 03.11.16).

Paulino, P.V.R., 2006. Desempenho, composição corporal e exigências nutricionais de bovinos Nelore de diferentes classes sexuais. Thesis (Doctor in zootechny). Federal University of Viçosa, Viçosa, MG, Brazil (in Portuguese). Available at: http://locus.ufv.br/handle/123456789/1708 (Accessed: 03 November 2016).

Pereira, R.G., Tulcan, O.E.P., Fellows, C.E., 2012. Sustainability and mitigation of greenhouse gases using ethyl beef tallow biodiesel in energy generation. J. Clean. Prod. 29-30, 269-276. http://dx doi.org/10.1016/j.jclepro.2012.01.007.

Pre-sustainability, 2016. SimaPro 8. Database and Methods Library. Available at: www.pre-sustainability.com/simapro-database-and-methods-library (Accessed: 06 November 2016).

Rico, J.A.P., Sauer, I.L., 2015. A review of Brazilian biodiesel experiences. Renew. Sustain. Energy Rev. 45, 513-529. http://dx.doi.org/10.1016/j.rser.2015.01.028.

Rincón, L.E., Jaramillo, J.J., Cardona, C.A., 2014. Comparison of feedstocks and technologies for biodiesel production: an environmental and techno-economic evaluation. Renew. Energy 69, 479-487. http://dx.doi.org/10.1016/ j.renene.2014.03.058.

Rocha, M.H., Capaz, R.S., Lora, E.E.S., Nogueira, L.A.H., Leme, M.M.V., Renó, M.L.G., Olmo, O.A., 2014. Life cycle assessment (LCA) for biofuels in Brazilian conditions: a meta-analysis. Renew. Sustain. Energy Rev. 37, 435-459. http:// dx.doi.org/10.1016/j.rser.2014.05.036.

Ruviaro, C.F., de Léis, C.M., Lampert, V.N., Barcellos, J.O.J., Dewes, H., 2015. Carbon footprint in different beef production systems on a southern Brazilian farm: a case study. J. Clean. Prod. 96, 435-443. http://dx.doi.org/10.1016/ j.jclepro.2014.01.037.

Siqueira, T.T.S., Duru, M., 2016. Economics and environmental performance issues of a typical Amazonian beef farm: a case study. J. Clean. Prod. 112, 2485-2494. http://dx.doi.org/10.1016/j.jclepro.2015.10.032.

Thamsiriroj, T.J.D., Murphy, J.D. 2011a. The impact of the life cycle analysis methodology on whether biodiesel produced from residues can meet the EU sustainability criteria for biofuel facilities constructed after 2017. Renew. Energy 36, 50-63. http://dx.doi.org/10.1016/j.renene.2010.05.018.

Thamsiriroj, T.J.D., Murphy, J.D., 2011b. A critical review of the applicability of biodiesel and grass biomethane as biofuels to satisfy both biofuel targets and sustainability criteria. Appl. Energy 88 (4), 1008-1019. http://dx.doi.org 10.1016/j.apenergy.2010.10.026.

UNFCCC, November 2008. United Nations Framework convention on climate change. In: Report of 35th Meeting of the Methodologies Panel of CDM - Annex 11-Draft Guidance on Apportioning of Emissions Top Co-products and Byproducts. Bonn, Germany, pp. 3-7.

USDA, 2016. Foreign Agricultural Service. Livestock and Poultry: World Markets and Trade. United States Department of Agriculture. Available at: http://apps.fas. usda.gov/psdonline/circulars/livestock_poultry.pdf (Accessed: 31 October 2016.)

USGS, 2016. United States Geological Survey. Available at: http://landsat.usgs.gov/ L8 band_combos.php (Accessed: 22 September 2016.).

Valadares Filho, S.C., Marcondes, M.I., Chizzotti, M.I., Paulino, P.V.R., 2010. In: Viçosa, M.G. (Ed.), Exigencias nutricionais de zebuínos puros e cruzados BRCORTE, 2 ed. UFV, Suprema Gráfica Ltda., Brazil, p. 193. 